\title{
Wykorzystanie obiektu zabytkowego o charakterze użyteczności publicznej na współczesną funkcję użytkową
}

\author{
(Na przykładzie przytułku-szpitala w zespole sakralnym parafii \\ rzymsko-katolickiej p.w. Przemienienia Pańskiego w miejscowości \\ Sawin w powiecie chełmskim w województwie lubelskim)
}

\author{
Mieczysław Brzozowski, Katarzyna Święcicka-Brzozowska \\ e-mail: brzozowskipulawy@op.pl,ksbrzozowska@wp.pl
}

\begin{abstract}
Streszczenie: Niniejszy artykuł opisuje koncepcję wykorzystania Szpitala-Przytułku w Sawinie jako obiektu zabytkowego o charakterze użyteczności publicznej na współczesną funkcję użytkową. We wstępie autor ukazuje rys historyczny obiektu stworzony na podstawie zarówno opracowań, jak i dokumentów i ekspertyz uzyskanych od właściwych urzędów i jednostek administracyjnych. W późniejszej części przedstawiono stan obecny budynku sporządzony na podstawie szczegółowej inwentaryzacji wykonanej za pomocą najnowocześniejszego sprzętu specjalistycznego. Zwieńczenie stanowi przedstawienie założeń projektu rewitalizacji obiektu, który służyć będzie Regionalnemu Towarzystwu Gminy Sawin w celu realizacji celów statutowych.
\end{abstract}

Słowa kluczowe: historyczny budynek, nowoczesne funkcje.

\section{Wstęp}

Sawin, niegdyś miasteczko, obecnie wieś położona w powiecie chełmskim, może poszczycić się bogatą i chlubną historią. Pierwsze wzmianki na temat lokacji miasta na prawie magdeburskim pojawiły się około 1492 roku, kiedy to biskup chełmski Maciej ze Starej Łomży, herbu Rawicz( stąd Rawicz przyjęty jako herb miasta), wyjednał dla Sawina u króla Jana Olbrachta przywilej miejski. Akt był jeszcze parokrotnie potwierdzony przez kolejnych królów. Zawsze jednak Sawin stanowił integralną część Ziemi Chełmskiej i własność tamtejszych biskupów. Historia miejscowości nie zaczyna się jednakże w momencie uzyskania praw miejskich, ale sięga czasów wczesnego średniowiecza, a więc wieków IX i X. Korzenie osadnictwa można łączyć z historią plemienia Lędzian, którzy zarządzali tą częścią Ziemi Chełmskiej, stanowiącej równocześnie część Grodów Czerwieńskich aż do roku 981, kiedy to zostały zajęte przez księcia kijowskiego Włodzimierza. Następne lata obfitowały w walki o Ziemię Chełmską pomiędzy królami polskimi, Piastami, a książętami Rusi Kijowskiej.

W roku 1456 król Kazimierz Jagiellończyk przekazał dobra sawińskie biskupom chełmskim obrządku łacińskiego. Po pierwszej lokacji w 1492 r. prawa miejskie Sawina miały następne nadania królewskie - Aleksandra Jagiellończyka w roku 1506 oraz Zygmunta Starego w roku 1537. Również król Zygmunt August okazał Sawinowi łaskę i na wniosek biskupa chełmskiego Jana Przerębskiego nadał Sawinowi w 1559 roku przywilej „przewozowy”. Oznaczało to zwolnienie mieszczan od opłat celnych (m.in. mostowego, grobelnego, przewoźnego) w całym Królestwie. W roku 1589 przywileje zostały potwierdzone przez króla Zygmunta III. 
Opisane dzieje historyczne Sawina ilustruje poniższa tabela, w której zawarto wybrane wydarzenia odnosząc się do Rzeczypospolitej, Ziemi Chełmskiej oraz Sawina.

Tabela 1. Dzieje Sawina ukazane na tle wydarzeń historycznych Ziemi Chełmskiej i Rzeczypospolitej. Źródło: Oprac. własne

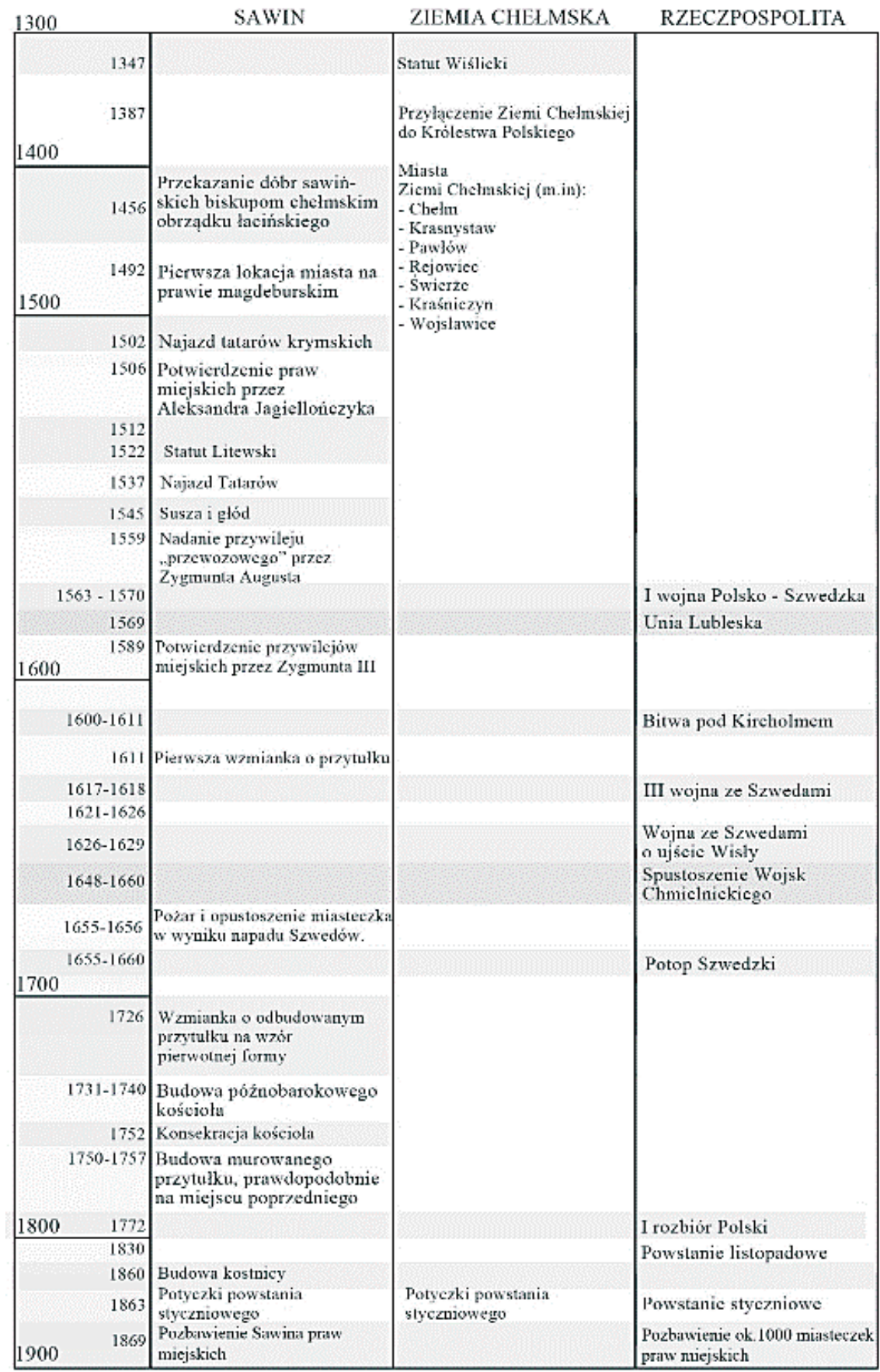




\section{Przytułek-szpital}

Budynek przytułku - szpitala, a szczególnie jego parter ze sklepieniami i charakterystycznym kominem, to $\mathrm{z}$ pewnością jeden $\mathrm{z}$ niewielu obiektów zachowanych $\mathrm{w}$ stanie oryginalnym. Zgodnie z tzw. Biała Karta 3 opracowaną przez mgr. Wojciecha Pietrzaka w 2000 roku, szpital w zespole kościelnym w Sawinie przy ul. Kościelnej 16 stanowi własność Parafii Rzymsko-Katolickiej. Budynek został wpisany do rejestru zabytków decyzją A/400/69 z dnia 21.01.1969 roku. Administracyjny nadzór konserwatorski sprawuje Wojewódzki Urząd Ochrony Zabytków w Lublinie, Delegatura w Chełmie.

Od połowy XV wieku w Sawinie mieli swoją rezydencję biskupi chełmscy. Nieistniejący już pałac biskupi zlokalizowany był w niewielkiej odległości od kościoła. Ówczesne struktury władzy i relacje kościelno-królewskie były uregulowane i ściśle określone. Wszelkie dobra były ustalone i nie powodowały na ogół konfliktów i rozwarstwień. Zarówno majątki dworskie jak też królewskie nie konkurowały ze sobą, tworząc równoległe możliwości rozwoju osadnictwa i rozwoju gospodarczego. Kościół troszcząc się o własną prosperitę, tworzył miasteczka i majątki dzierżawione zarówno ziemianom, jak też mieszczanom. Dbał o dochody oraz rozwój terenów zamieszkiwanych przez miejscową ludność.

Lokacja Sawina na prawie magdeburskim przyczyniła się do powstania struktur miejskich. Biskupi w sposób oczywisty byli przeciwni osadnictwu Żydów, co skutkowało ograniczeniami w rozwoju handlu i rzemiosła. Była to blokada dla rozwoju wielofunkcyjnego i przestrzennego Sawina. W związku z powyższym, braki w infrastrukturze komunalnej zaspokajano w sposób najprostszy i na miarę pojawiających się potrzeb. Jednym z takich sposobów była pierwsza lokacja Przytułku-Szpitala.

W ramach niniejszego opracowania przedstawiono związek przyczynowo skutkowy powstawania tego typu obiektów. Szpitalik z przytułkiem był formą egzystencji w ramach dóbr biskupich. Zapewniał zarówno prawidłowe funkcjonowanie administracji kościelnej, jak też funkcjonującej równolegle ludności świeckiej.

Do 1726 roku przy ulicy Kościelnej istniał najprawdopodobniej drewniany kościół oraz siedziba biskupów. W 1611 roku pojawiła się wzmianka, że fundatorem bocznego ołtarza kościoła był Paweł Chyliński. Przy tej okazji ufundował on również wyposażenie przytułku. Można więc podejrzewać, że obiekt istniał już wcześniej, a został wyłącznie zabezpieczony przez filantropa. Na miejscu istniejącego, z inicjatywy miejscowego proboszcza, zbudowano nowy przytułek, który był przeznaczony dla pięciu ubogich. W latach 1655-1656 w wyniku napadu Szwedów, obiekt wraz z miasteczkiem został spalony.

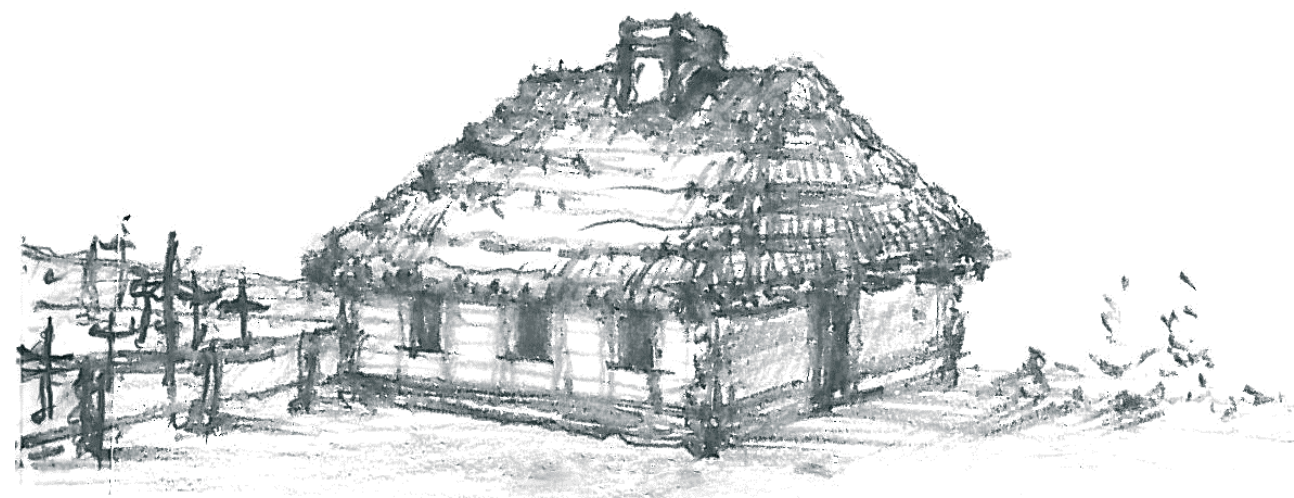

Rys. 1. Domniemany pierwotny kształt Przytułku - Szpitala. Odwzorowanie na podstawie zachowanych przykładów architektury drewnianej. Źródło: Oprac. własne 
W latach 1731-1740 za sprawą Barbary z Podowskich Dłużewskiej, kasztelanowej chełmskiej, oraz jej syna Stanisława, wybudowany został kościół murowany. Decyzja o budowie kolejnego Przytułku-Szpitala została podjęta w 1750 roku. Budynek został oddany do użytku w 1757 roku stanowiąc swoisty szpital dla sześciorga ubogich - trzech mężczyzn i trzech kobiet. Pomimo kilkakrotnych remontów, mających miejsce w późniejszych czasach, obiekt w stanie niezmienionym przetrwał do dziś. Użytkowany był do lat siedemdziesiątych XX wieku.

W pierwotnej wersji budynek był zbudowany z drewna, z dachem kopertowym poszytym strzechą. Najprawdopodobniej uległ zniszczeniu w wyniku pożaru roznieconego przez Szwedów, podczas wojny północnej. Przytułek od początku pełnił tę samą rolę zamieszkiwało go pięcioro, próżniej sześcioro ubogich utrzymujących się z darów ofiarowanych przez parafian i proboszczów oraz obowiązkowej pracy w przykościelnym ogrodzie i cmentarzu grzebalnym zlokalizowanym bezpośrednio przy kościele. Budynek znajdował się przy obecnej ulicy Kościelnej, nieopodal rezydencji biskupów chełmskich i drewnianego kościoła, które przetrwały tragiczny napad. Przytułek przed 1726 rokiem odbudowano w pierwotnej formie, jednak w roku 1750 zdecydowano się radykalnie go przebudować, murując tym razem ściany, sklepienia i komin. Budowę zakończono w 1757 roku. Fundatorem był proboszcz Józef Suchocki. Inwentarz z 1890 roku opisuje, że obiekt miał sześć izb, po trzy po każdej stronie korytarza, zlokalizowanego w osi budynku. We wszystkich izbach istniały rozbudowane o części grzewcze - kuchnie do gotowania. W skrajnych izbach umiejscowiono piece ceglane, które ogrzewały również pomieszczenia środkowe. Z korytarza było wyjście na teren przykościelnego cmentarza i drugie na plac publiczny. W latach 1731-1740 do murowanego kościoła dobudowano dzwonnicę w stylu późnobarokowym. Uroczystej konsekracji kompleksu pod wezwaniem Przemienienia Pańskiego dokonano 22 listopada 1752 roku.

Decyzja o realizacji nowego kościoła (lata 1731-1740) została podjęta w sposób nieprzemyślany, bez prawidłowego rozpoznania warunków gruntowo-wodnych, a przede wszystkim geologicznych. Lokalizacja i realizacja kościoła wymusiła konieczność szybkiej reakcji w postaci wzmacniania i napraw murów oraz sklepienia. Nie zachowały się archiwalia dotyczące projektów i budowy kościoła. Wszystkie dokumenty dotyczące realizacji późnobarokowego kościoła uległy spaleniu podczas pożaru plebanii.

Następnie, na skutek złego posadowienia kościół wymagał wielokrotnych napraw i wzmocnień. Często ujawniające się błędy skutkowały koniecznością pracochłonnych działań doraźnych. Wspomnieć należy również, że kościół był usytuowany w obrębie czynnego cmentarza grzebalnego. Lokalizacja przytułku-szpitala na skraju posesji, w północno-wschodnim narożniku była zatem logicznie uzasadniona. Lokatorzy mieli obowiązek świadczenia pracy na rzecz zarówno cmentarza, jak też kościoła i plebanii. Prawdopodobnie w roku 1798 cmentarz kościelny przestał być miejscem pochówków i został przeniesiony w nowe, bezpieczne dla miasta miejsce.

W roku 1860 do szpitala dobudowano kostnicę. Była to reakcja na panującą wówczas epidemię cholery. W latach 1936 - 1946, kiedy funkcję proboszcza sprawował ks. Zygmunt Grzegorzewski, wykonano remont plebanii oraz przytułku. Otynkowano budynki oraz wymieniono pokrycie dachu na blachę. Przytułek był użytkowany nieprzetrwanie do $1972 \mathrm{r}$.

Zestawienie rysunków 4,5,6 przedstawiających kolejno, fragment frontu kościoła oraz domniemany pierwotny wygląd murowanego przytułku-szpitalika obrazuje analizę domniemanej elewacji wejściowej szpitalika $\mathrm{w}$ odniesieniu do zachowanych oryginalnych fragmentów oraz być może bezpośredniego związku z fasadą kościoła. 


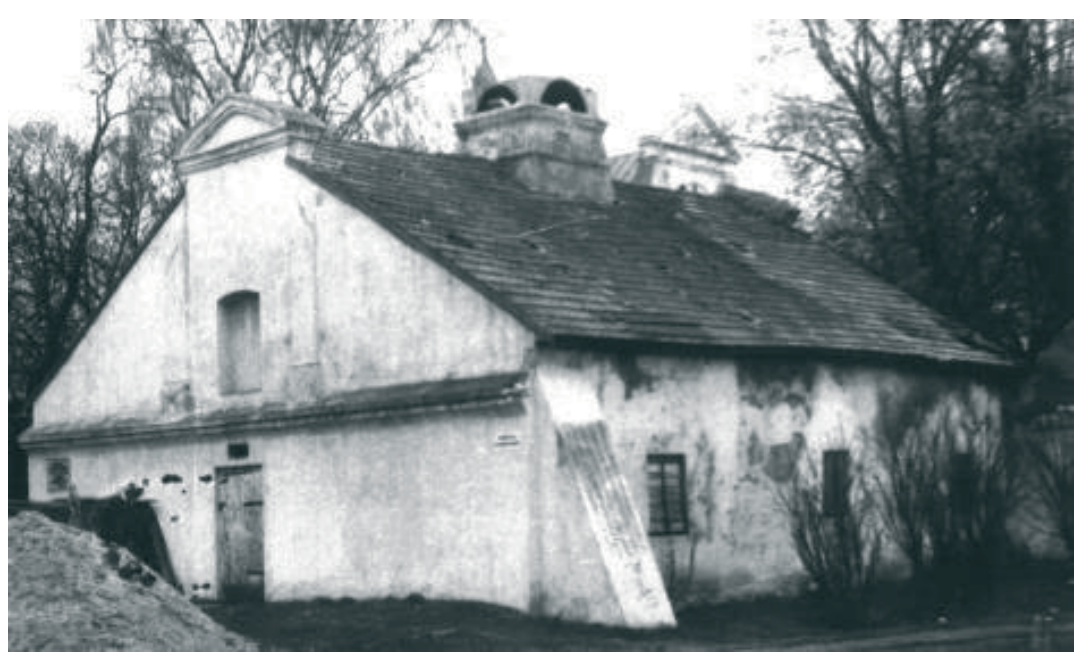

Rys. 2. Szpitalik murowany z 1757 r. - elewacje północna i zachodnia - lata 70. Źródło: wł. W. Libery

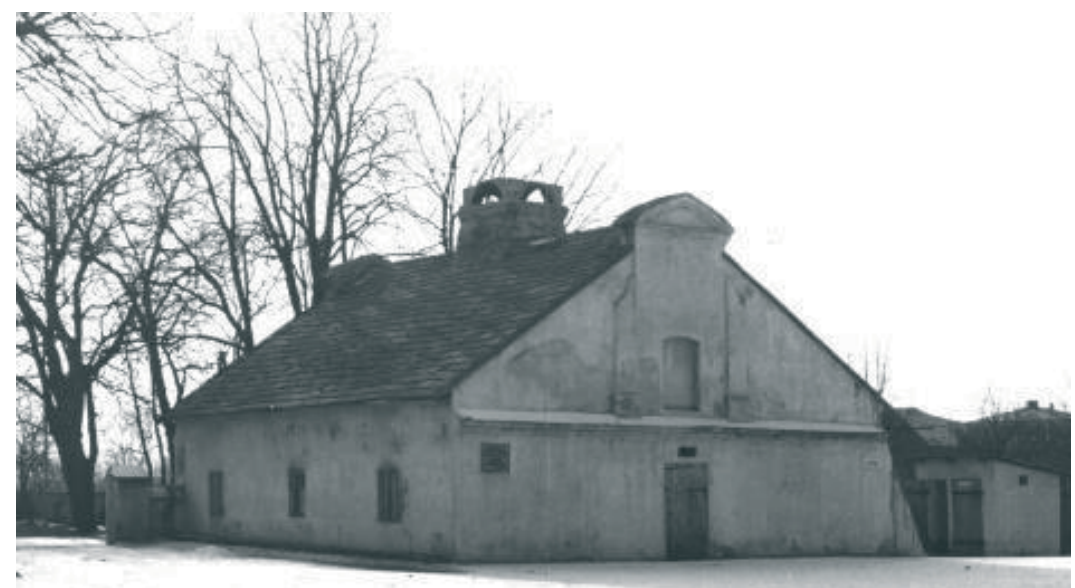

Rys. 3. Szpitalik murowany z 1757 r. - elewacje północna i wschodnia - lata 70. Źródło: wł. W. Libery

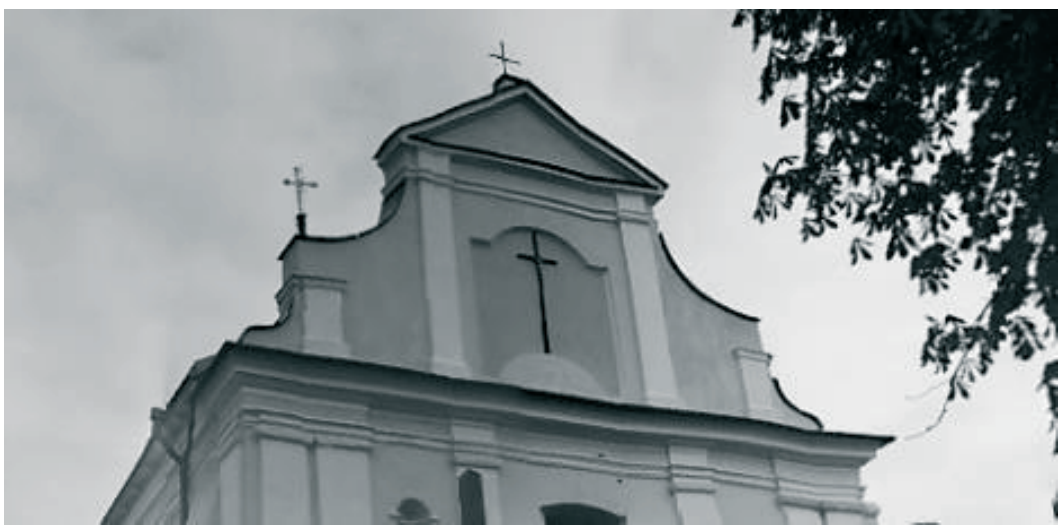

Rys. 4. Widok górnej części fasady kościoła Parafii Rzymskokatolickiej w Sawinie. Źródło: Google Street View 


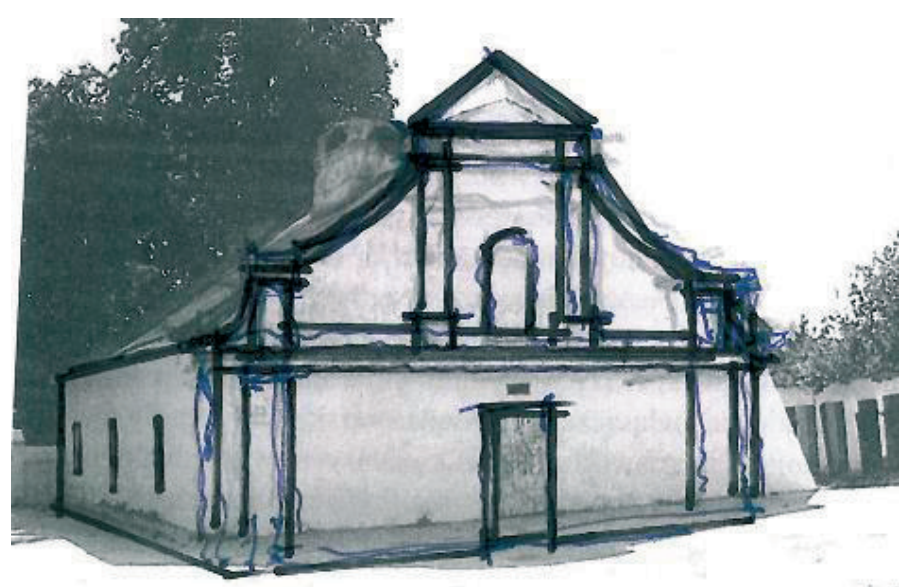

Rys. 5. Domniemany kształt pierwotnej wersji murowanego szpitalika. Źródło: Błaszczuk S., Ćwir J., Wiciński H., Dzieje Parafii Rzymskokatolickiej oraz innych kościołów i związków wyznaniowych w Sawinie, Wyd. Drukarnia Kresowa Chełm, Sawin 2006, s. 169

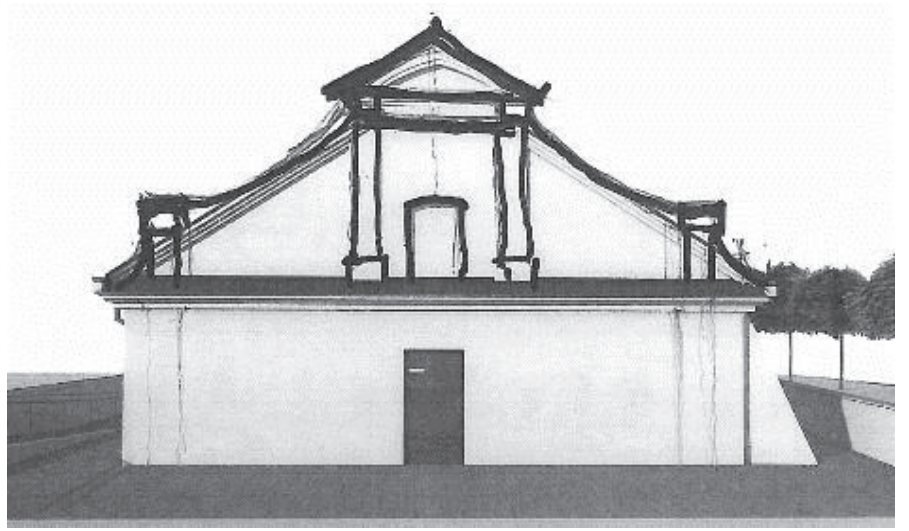

Rys. 6. Domniemany wygląd północnej elewacji przytułku - szpitala. Źródło: Oprac. własne

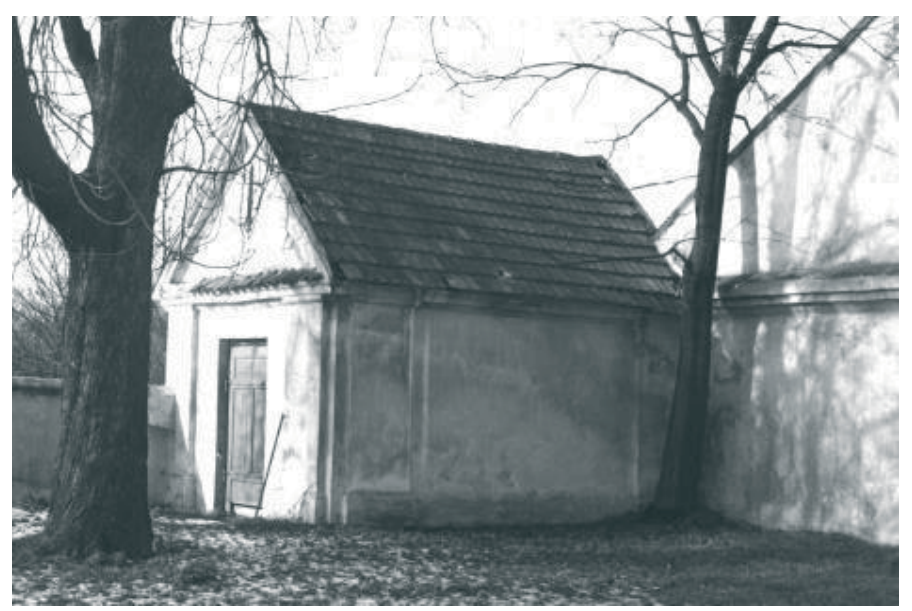

Rys. 7. Kostnica - lata 70. Źródło: wł. W. Libery 


\section{Opis stanu istniejącego}

W celu prawidłowej oceny stanu istniejącego dokonano szczegółowej inwentaryzacji, zgodnie z umową zawartą z Regionalnym Towarzystwem Gminy Sawin (RTGS). Opracowanie w sposób precyzyjny odzwierciedla zarówno stan techniczny, jak też stan zachowania przytułku-szpitala z kostnicą w Sawinie. Ze względu na swoje położenie geograficzne oraz inne historyczno-polityczne aspekty, obiekt nie utracił żadnego ze swoich walorów i doskonale zachował charakter i klimat dawnych, ale ciągle aktualnych problemów. Stanowi najlepszy przykład sposobu rozwiązywania problemów społecznych w zakresie wykorzystania zabytkowej substancji na funkcje o charakterze użyteczności publicznej. WUOZ obiekt opisuje w sposób następujący: Przytułek jest obiektem parterowym, niepodpiwniczonym, nakrytym dwuspadowym dachem, z ozdobnymi szczytami od strony północnej $i$ potudniowej. Obecnie budynek pokryty jest eternitem. W kalenicy dachu jest szeroki ogzymsowany komin, z ostrostupowa czapa wsparta na czterech arkadach. Ściany budynku murowane z cegty, obustronnie otynkowane. Elewacje wschodnia i zachodnia proste trójosiowe, bez detalu architektonicznego. W osiach nieduże drewniane dwuskrzydtowe, czteropolowe okna. Elewacja pólnocna i południowa odcięta od szczytów wydatnymi prostymi gzymsami. W osi elewacji pótnocnej zlokalizowany jest prostokątny otwór drzwiowy stanowiący wejście do budynku. Drzwi wejściowe drewniane, deskowe na pasowych zawiasach, zachodnie naroża budynku wsparte skośnymi skarpami - przyporami. Wnętrze budynku na planie prostokata, dwu i pót traktowe, z waskim wzdlużonym korytarzem nakrytym sklepieniem kolebkowym. W obu traktach po trzy pomieszczenia zbliżone wielkościa, nakryte sklepieniami kolebkowo-krzyżowymi. We wszystkich pomieszczeniach ceglane posadzki. Drzwi wewnętrzne analogiczne do wejściowychl ${ }^{\text {. }}$

$\mathrm{W}$ ramach inwentaryzacji obiektu wykonano zdjęcia i rysunki aktualnego stanu. Budynek znajduje się w bardzo złym stanie, więc wykonanie robót remontowych jest zasadne. Jako przyczyny złej kondycji obiektu należy wymienić bardzo duże zawilgocenie, brak ogrzewania i niewłaściwe odprowadzenie wody. Inwentaryzacja została dokonana przy pomocy bezpośrednich pomiarów z wykorzystaniem dalmierzy laserowych, miar oraz skanowania laserowego „3D”.

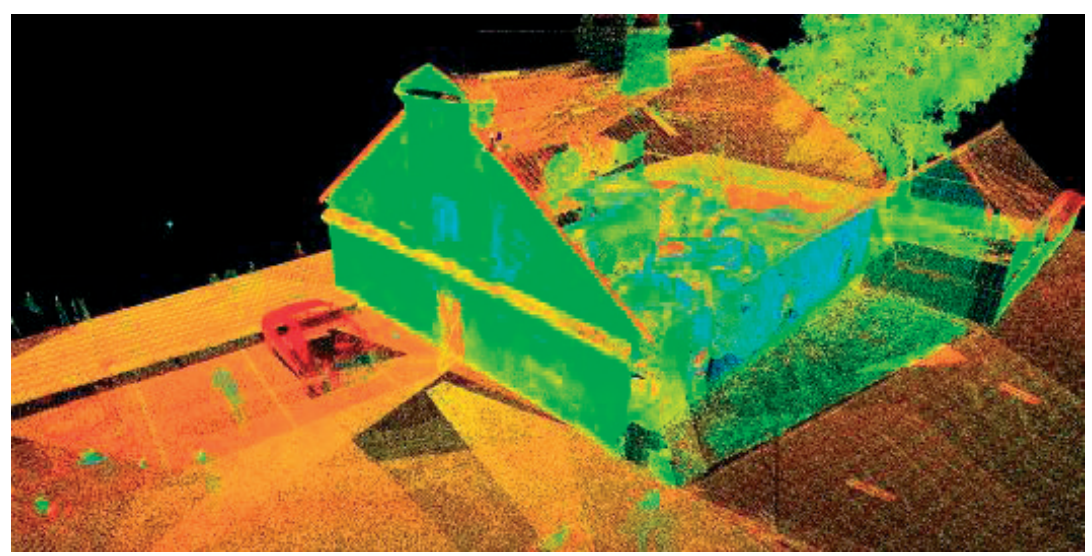

Rys. 8. Szpitalik - elewacje północna i zachodnia - skan laserowy. Źródło: Oprac. własne we współpracy $z$ dr. inż. arch. B. Kwiatkowskim

\footnotetext{
${ }^{1}$ Odpowiedź Wojewódzkiego Urzędu Ochrony Zabytków $w$ Lublinie, Delegatura $w$ Chetmie do Regionalnego Towarzystwa Gminy Sawin, znak: IN.II. 5142.67.1.2016 z dnia 12.04.2016 r.
} 


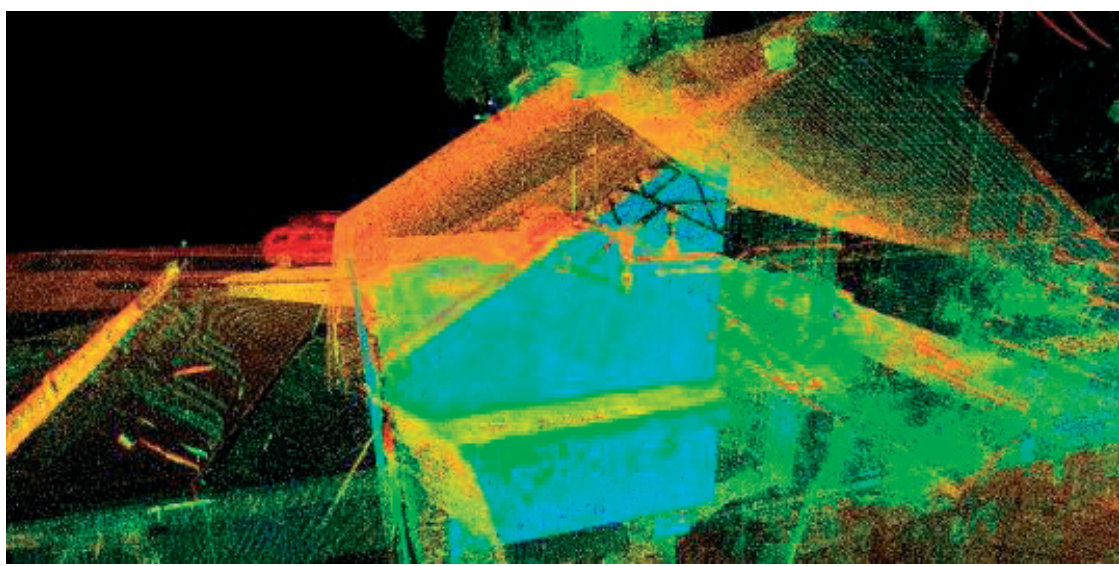

Rys. 9. Szpitalik - elewacje południowa i wschodnia - skan laserowy. Źródło: Oprac. własne we współpracy z dr. inż. arch. B. Kwiatkowskim

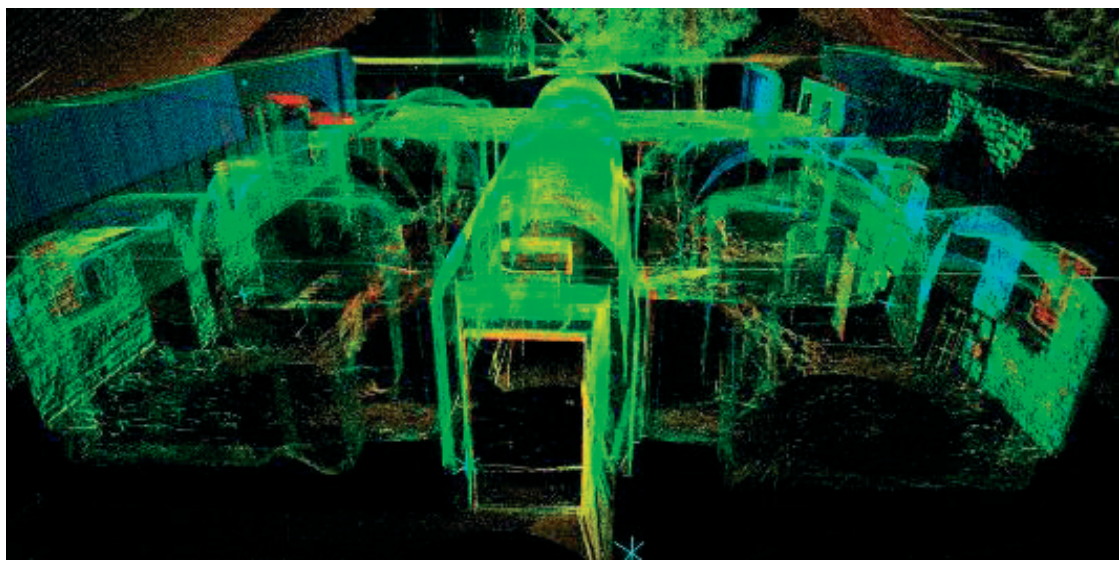

Rys. 10. Szpitalik - wnętrze budynku - skan laserowy. Źródło: Oprac. własne we współpracy z dr. inż. arch. B. Kwiatkowskim

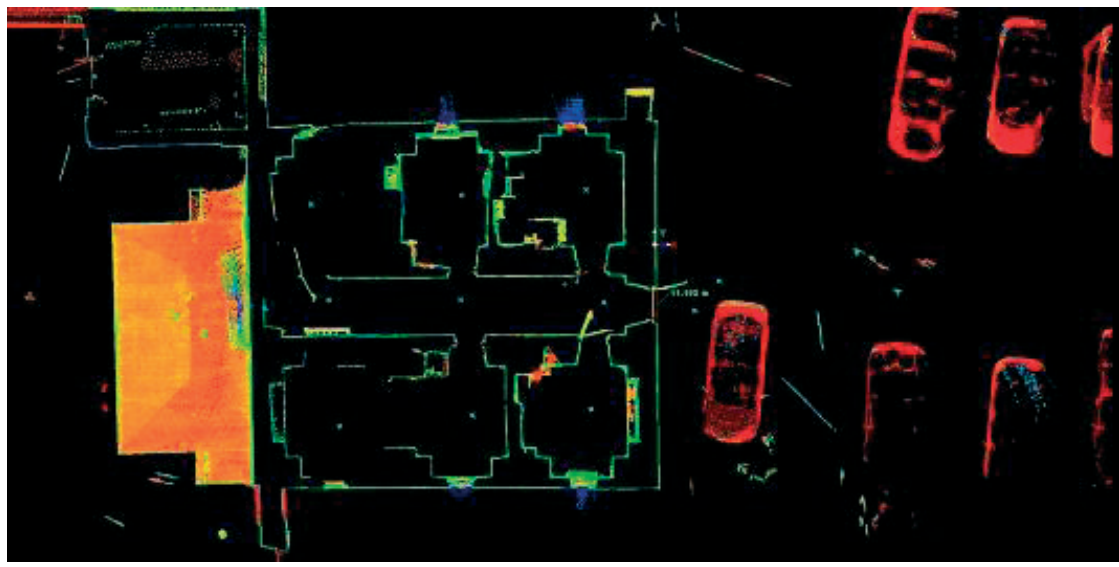

Rys. 11. Szpitalik - rzut na poziomie $110 \mathrm{~cm}$ - skan laserowy. Źródło: Oprac. własne we współpracy z dr. inż. arch. B. Kwiatkowskim 


\section{Rysunki inwentaryzacyjne}

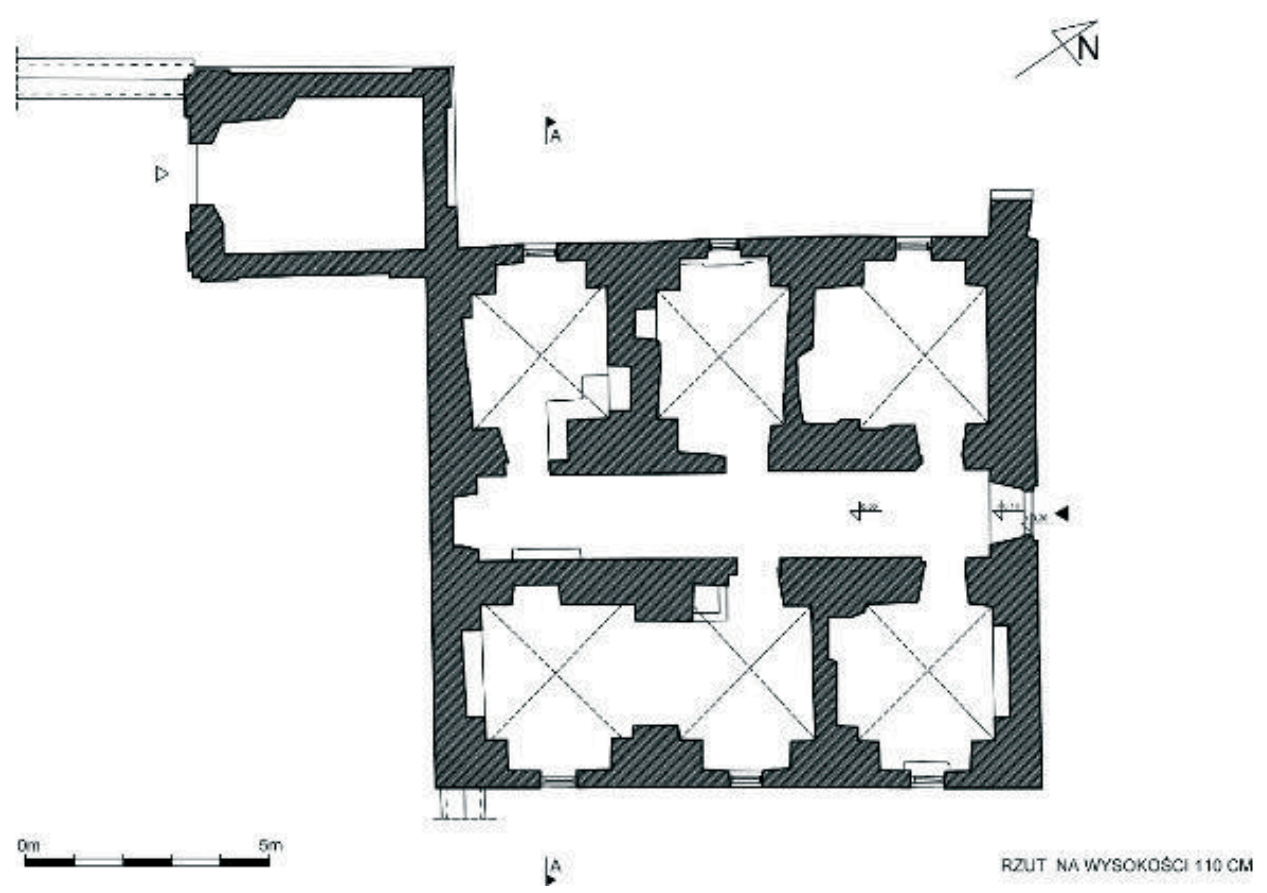

Rys. 12. Szpitalik - rzut na wysokości $110 \mathrm{~cm}$ - rysunek inwentaryzacyjny oznaczony podziałką liniową. Źródło: Oprac. własne

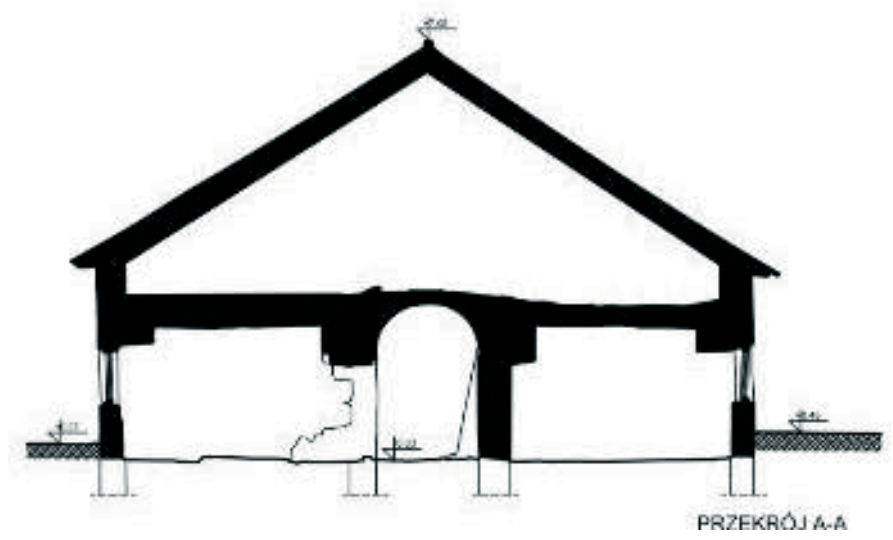

Rys. 13. Szpitalik - przekrój - rysunek inwentaryzacyjny oznaczony podziałką liniową. Źródło: Oprac. własne 


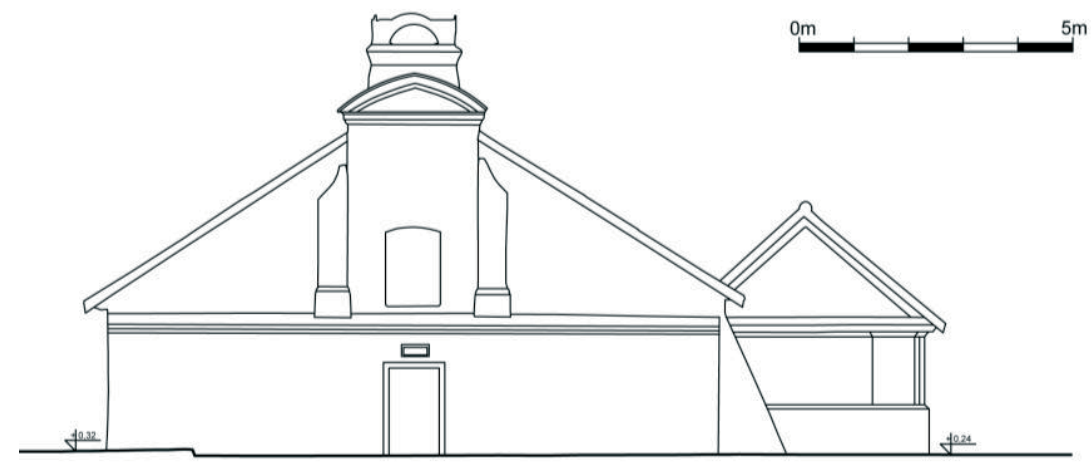

ELEWACJA PÓKNOCNA

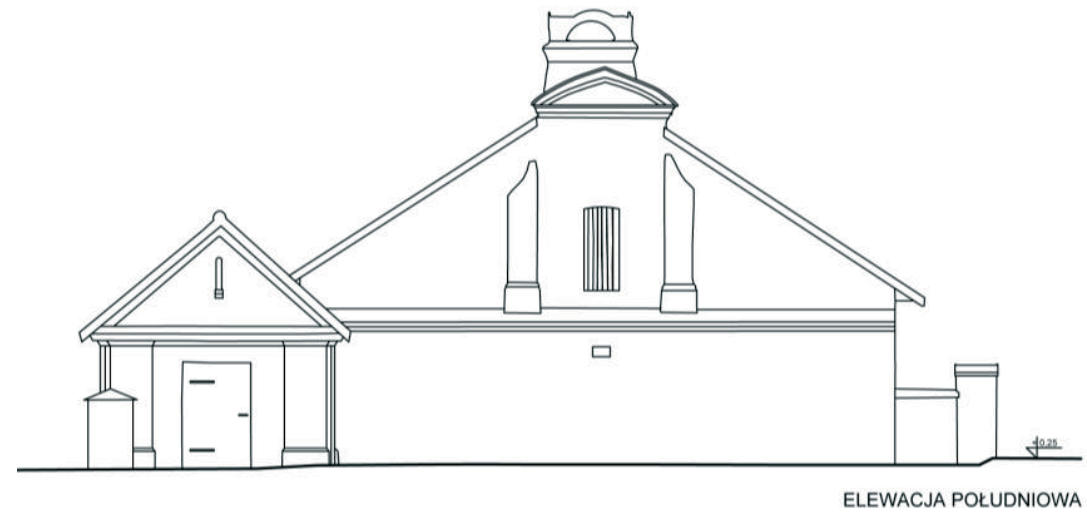

Rys. 14. Szpitalik - elewacja północna i południowa - rysunek inwentaryzacyjny oznaczony podziałką liniową. Źródło: Oprac. własne

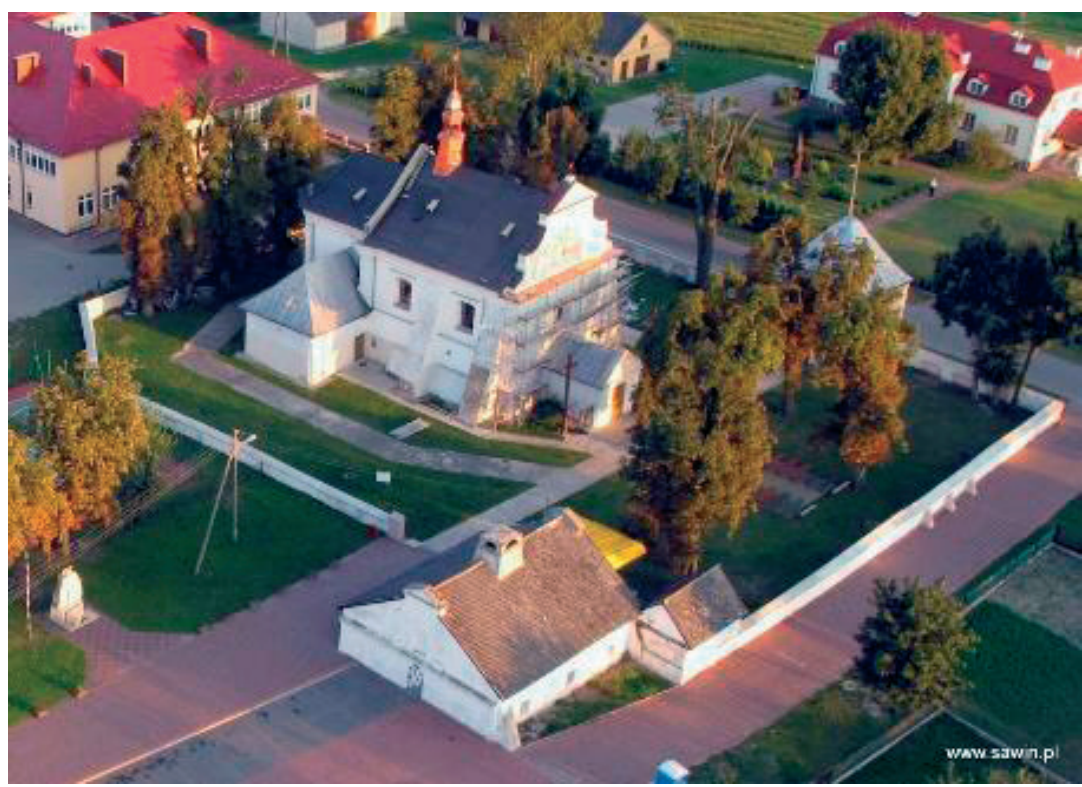

Rys. 15. Zespół sakralny - obecnie. Źródło: Gmina Sawin, www.sawin.pl [dostęp: 10.10.2016 r.] 


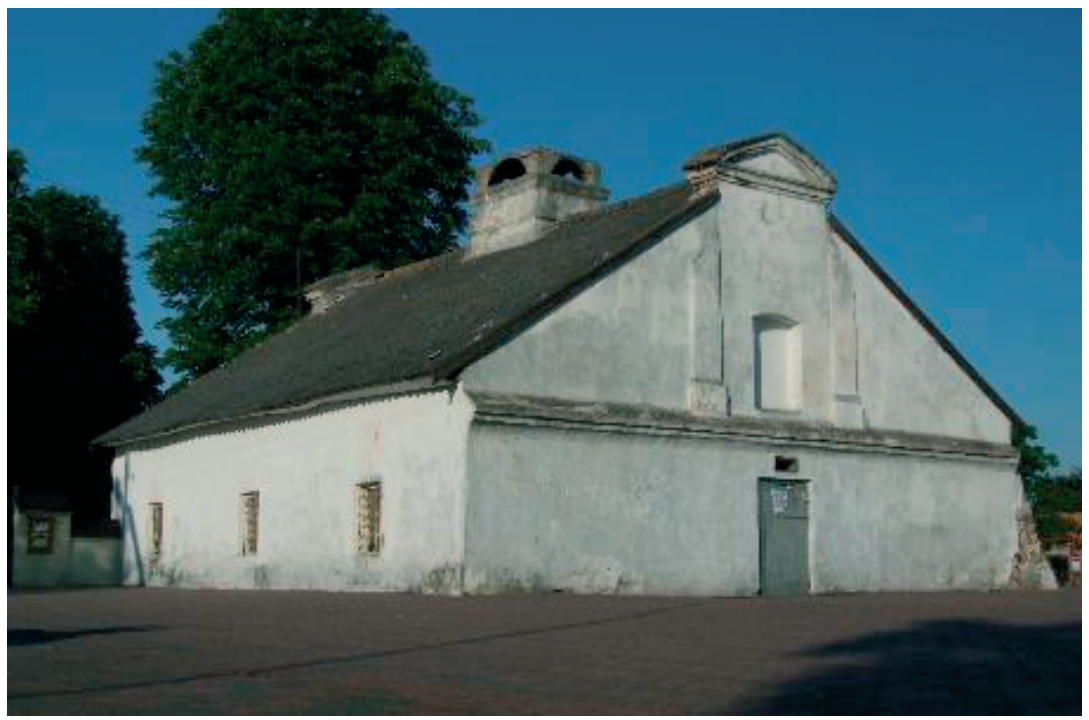

Rys. 16. Szpitalik - elewacje północna i wschodnia - obecnie. Źródło: Oprac. własne

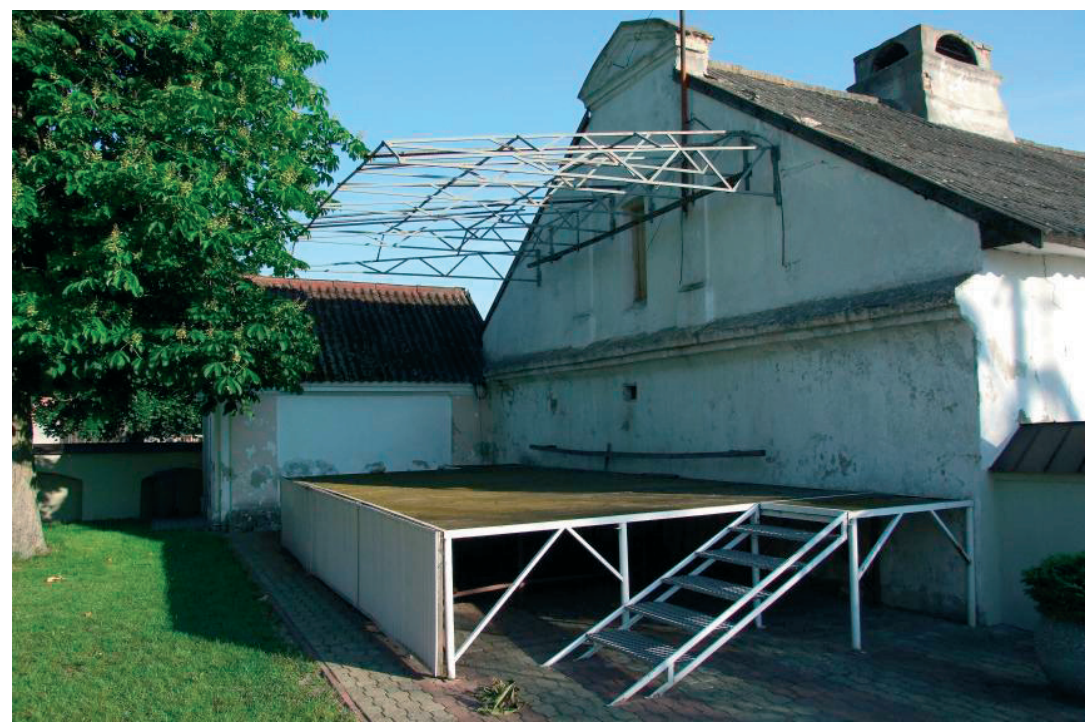

Rys. 17. Szpitalik - elewacja południowa i fragment kostnicy oraz scena - obecnie. Źródło: Oprac. własne

\section{Program i zakres rewitalizacji szpitalika-przytułku oraz kostnicy}

Przedmiotem opracowania jest rewitalizacja obiektu Szpitala-Przytułku oraz Kostnicy i adaptacja go na siedzibę Regionalnego Towarzystwa Gminy Sawin. Wykorzystywanie obiektu widniejącego w rejestrze zabytków jest procesem złożonym i wymaga starannego przygotowania. Należy zwrócić uwagę na jego indywidualny charakter i przestrzenny wyraz. Budynek po rewitalizacji tworzyłby przychylny człowiekowi klimat, oddziałując pozytywnie na jego psychikę. Aspekt przestrzenny i artystyczny takich budynków jest źródłem silnych wrażeń estetycznych, istotnie wpływających na odbiór otaczającego 
krajobrazu. Przystosowanie takiego obiektu dla funkcji o statusie publicznym może stworzyć łańcuch ciągłości kulturowej, spajający przeszłość z teraźniejszością, której odbiorca doświadcza poprzez czynny udział w życiu budynku.

Obecnie Szpitalik-Przytułek oraz Kostnica należą do Parafii Rzymsko-Katolickiej. Projekt przewiduje przekazanie obiektu na rzecz RTGS w celu prowadzenia statutowej działalności połączonej z prezentacją lokalnych produktów i wyrobów rzemieślniczych.

Przywracanie najstarszych rzemiosł wykonywanych w tym rejonie Ziemi Chełmskiej, a więc garncarstwa, bartnictwa, zielarstwa oraz rymarstwa. Wszelkie prace winny być wykonane przez wyspecjalizowaną firmę i pod ścisłym nadzorem służb konserwatorskich we współpracy $\mathrm{z}$ autorem projektu.

\section{Propozycja sposobu realizacji zamierzeń wobec realiów}

Zgodnie z założeniem przyjętym przez Towarzystwo Regionalne Gminy Sawin, Szpital-Przytułek wraz z Kostnicą zostanie, w sposób gruntowny i z zachowaniem wymogów sztuki konserwatorskiej, zrewitalizowany i przystosowany do aktualnie obowiązujących przepisów i wymogów formalnoprawnych oraz będzie użytkowany i wykorzystywany przez Towarzystwo Regionalne Gminy Sawin na cele statutowe.

Obiekt objęty rewitalizacją znajduje się na działkach budowlanych nr ew. 393 i 394 w Sawinie pow. chełmski. Od strony południowej teren inwestycji przylega do ul. Kościelnej, od strony północnej do ul. Brzeskiej.

Miejscowy plan zagospodarowania przestrzennego przeznacza ten teren pod usługi kultury - zespół sakralny (1UK). Działki zaś znajdują się w strefie ochrony ekspozycji i krajobrazu K i E, w obszarze Głównego Zbiornika Wód Podziemnych nr 407 (ChełmZamość) i obszarze najwyższej ochrony (ONO).

Zakres opracowania obejmuje projekt zagospodarowania działki oraz projekt architektoniczno-budowlany kompleksu składający się z części opisowej i rysunkowej.

Budynek dawnego przytułku jest obecnie nieużytkowany. Bryła obiektu jest stosunkowo prosta, z wejściem zlokalizowanym od strony północnej. Budynek został wykonany w technologii murowanej, z centralnie zlokalizowanym ciągiem komunikacyjnym wzdłuż podłużnej osi budynku. Do form architektonicznych występujących w budynku zaliczyć należy gzymsy, pilastry, przypory i nisze.

Ściany budynku planuje się zachować w konstrukcji murowanej, renowację sklepień - z przemurowaniami, remont komina z przemurowaniami i uzupełnieniami, a konstrukcję dachu - płatwiowo-kleszczową, w przypadku stwierdzenia takiej konieczności uzupełnić lub wymienić na nową. Poziom podłogi parteru budynku posadowiony jest obecnie na rzędnej 179,55 m n.p.m. Projektuje się obniżenie posadzki do rzędnej 178,82, co pozwoli na przywrócenie pomieszczeniom dawnych proporcji oraz właściwych wymiarów otworów drzwiowych. Powoduje to równocześnie konieczność obniżenia terenu otaczającego szpital oraz kostnicę. Sposób realizacji pokazano na rysunku projektu zagospodarowania terenu, jak też na przekrojach poprzecznych. Wspomnieć należy także o bezwzględnej konieczności dokonywania oceny stanu technicznego w trakcie realizacji ścian, zarówno zewnętrznych, jak też wewnętrznych całego budynku. Również w tym czasie musi zostać podjęta decyzja w sprawie sposobu wykonania izolacji poziomych oraz ewentualnej konieczności podbijania fundamentów.

Powierzchnia zabudowy wynosi $163,84 \mathrm{~m}^{2}$, a powierzchnia użytkowa około $87,06 \mathrm{~m}^{2}$. Kubatura brutto to blisko $790 \mathrm{~m}^{3}$. Wysokość $-8,78 \mathrm{~m}$, długość $-17,51 \mathrm{~m}$, szerokość - 16,68 m. Obiekt zachował jedną kondygnację nadziemną. Połacie nad główną 
częścią będą nachylone pod kątem $32^{\circ}$, a nad częścią sanitarną (kostnicą) pod kątem $40^{\circ}$. Poziom posadzki projektowanej znajduje się na rzędnej 178,82 m n.p.m.

W budynku głównym znajdować się będą pomieszczenia do pracy i ekspozycji, wpisując się w działalność statutową Regionalnego Towarzystwa Gminy Sawin, w których nie występują czynniki uciążliwe lub szkodliwe dla zdrowia. Pomieszczenia przeznaczone są na czasowy pobyt dla nie więcej niż czterech osób. Ich wysokość w świetle, w najniższym punkcie, wynosi 2,50 m.

Przewiduje się zachowanie historycznego układu pomieszczeń z wyjściem ewakuacyjnym w północnej elewacji budynku. Możliwa jest adaptacja jednego z pomieszczeń na zaplecze socjalne. W części budynku dawniej zajmowanego na kostnicę zaprojektowano zaplecze higienicznosanitarne. Zamieszczone poniżej ilustracje ukazują omówione wcześniej założenia.

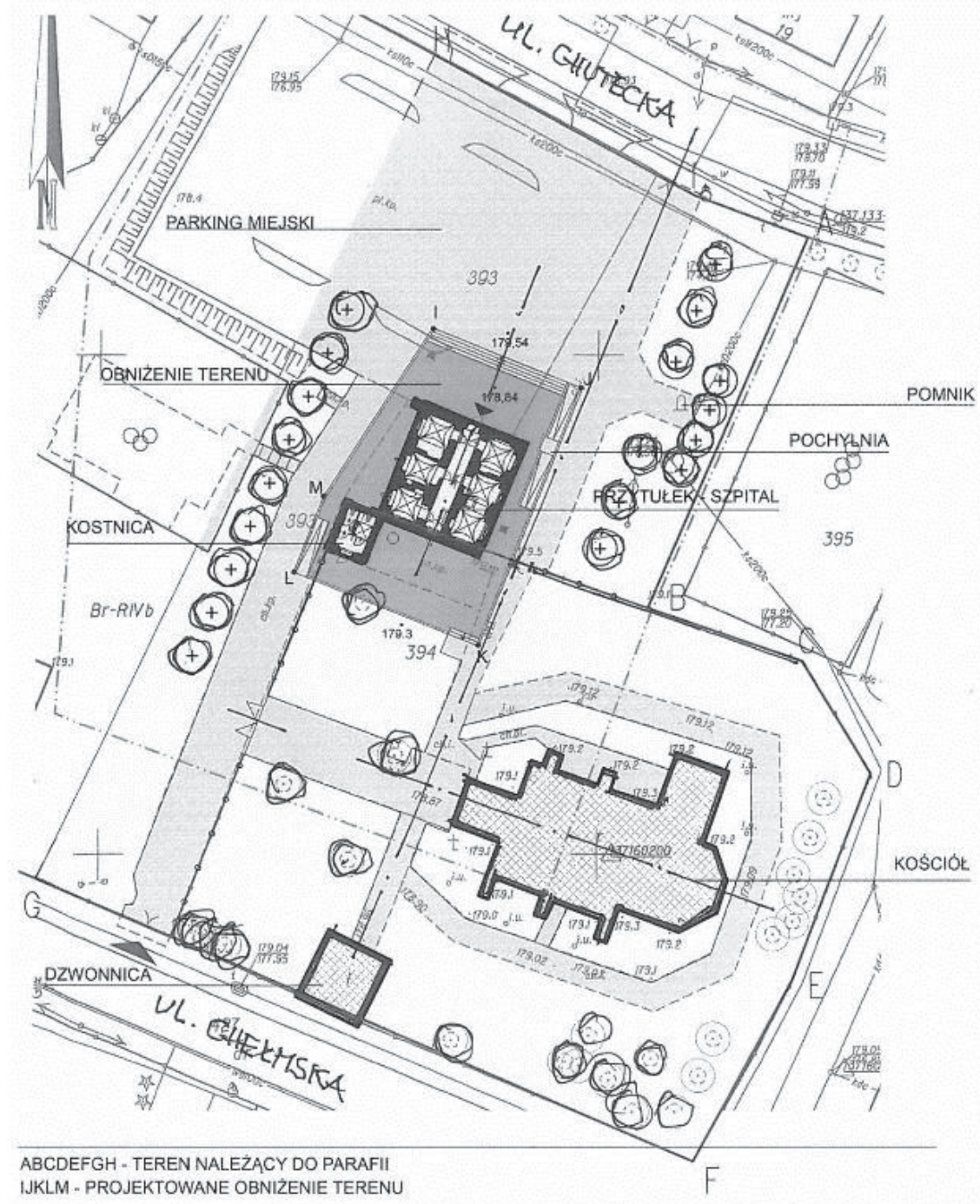

Rys. 18. Zespół sakralny - projekt zagospodarowania terenu. Źródło: Oprac. własne 


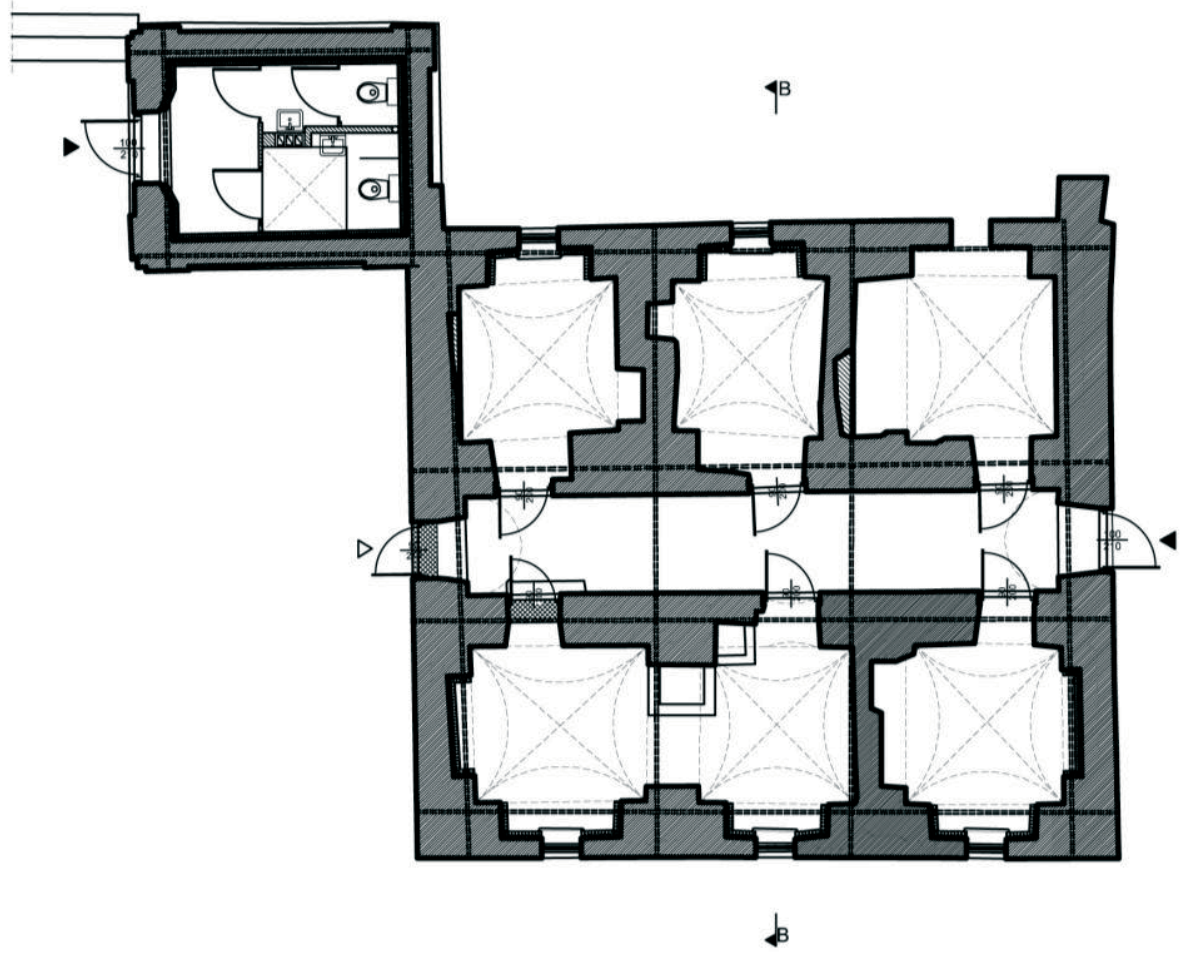

Rys. 19. Zespół sakralny - rzut - projekt. Źródło: Oprac. własne

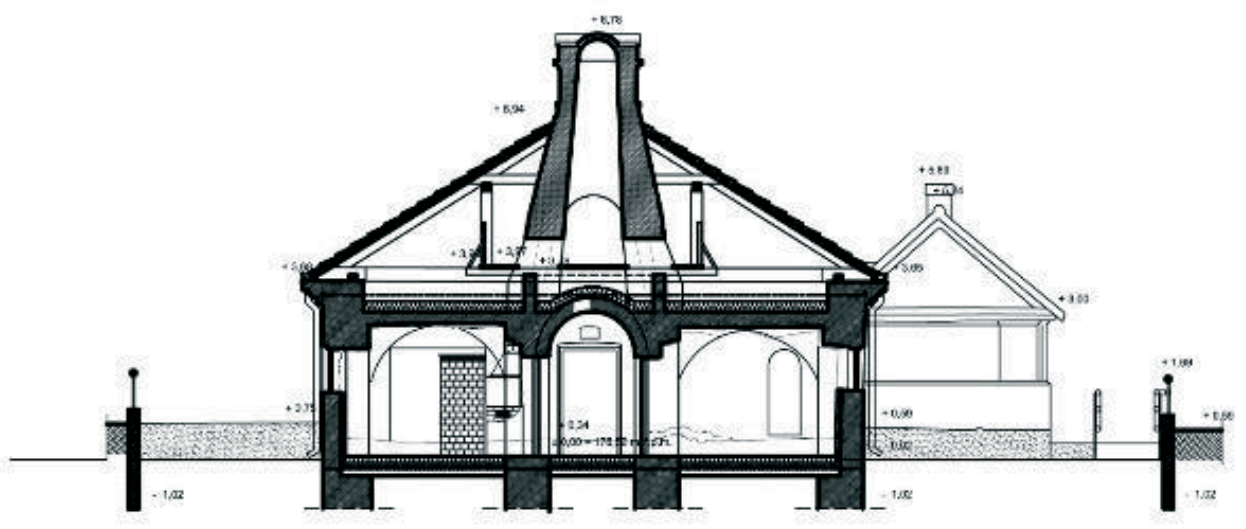

Rys. 20. Zespół sakralny - przekrój B-B - projekt. Źródło: Oprac. własne 


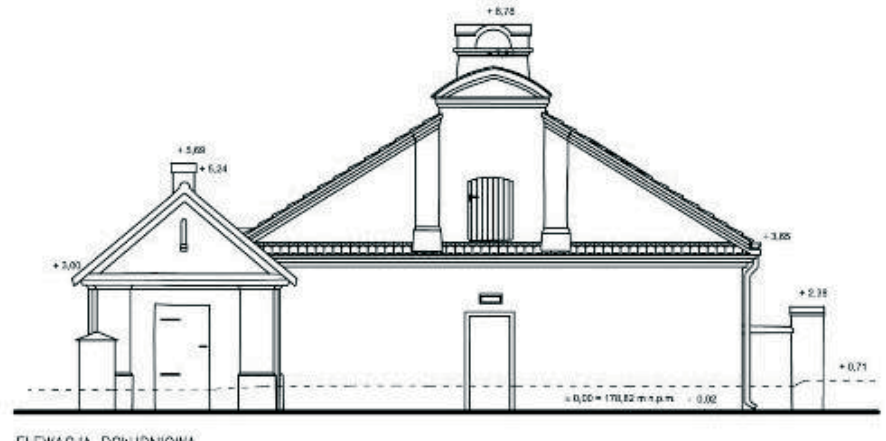

ELENACJA POKJONIOWA

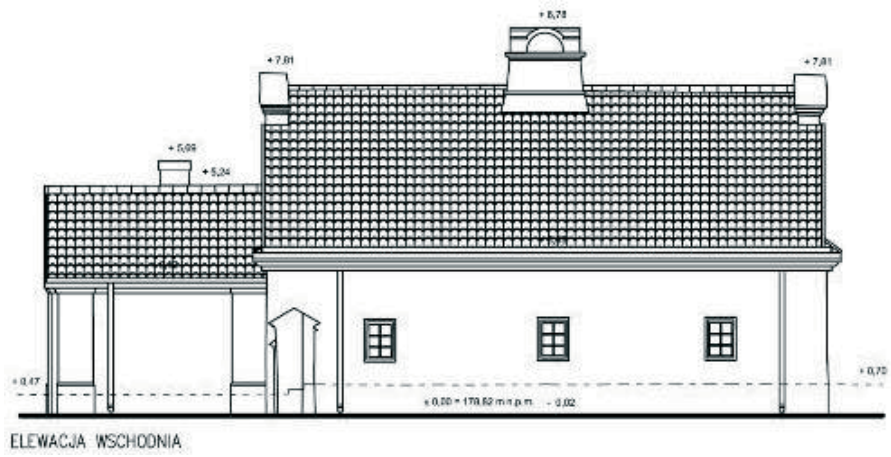

Rys. 21. Szpitalik wraz z kostnicą - elewacje południowa i wschodnia. Źródło: Oprac. własne
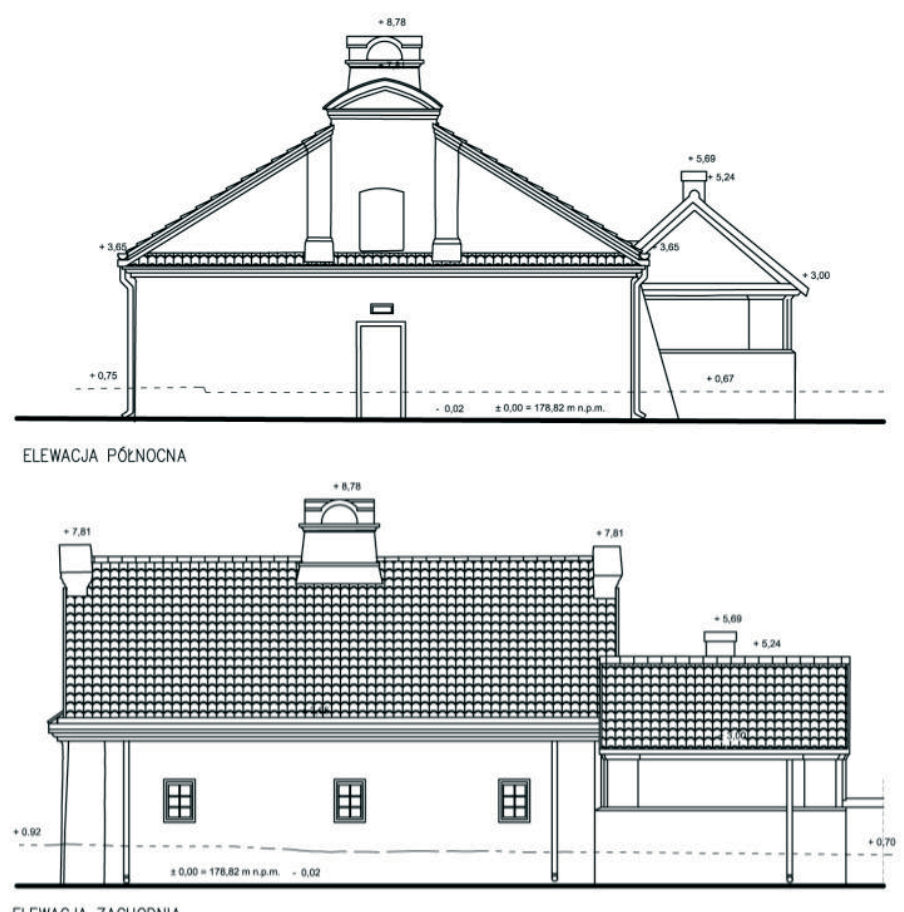

ELEWACJA ZACHODNIA

Rys. 22. Szpitalik wraz z kostnicą - elewacje północna i zachodnia. Źródło: Oprac. własne 


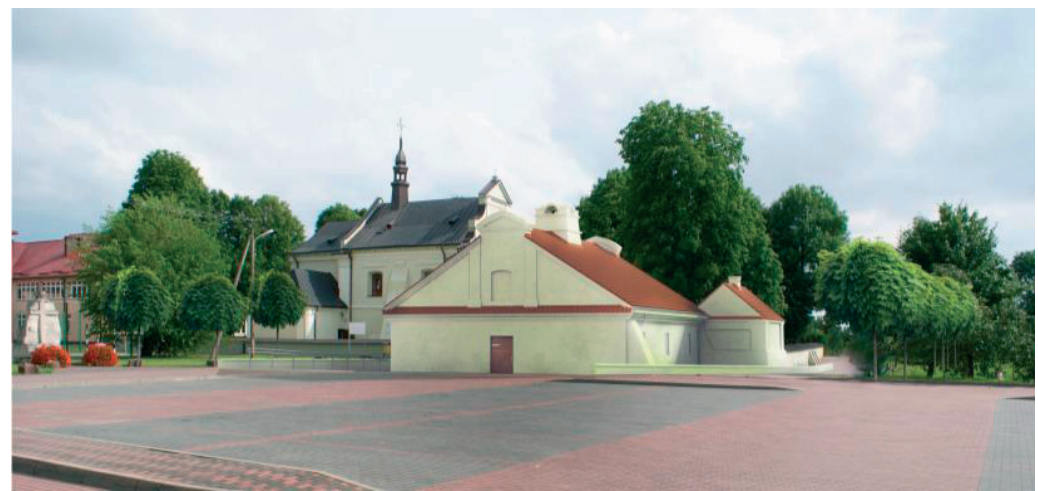

Rys. 23. Zespół sakralny - widok od strony północno-zachodniej - wizualizacja projektu. Źródło: Oprac. własne

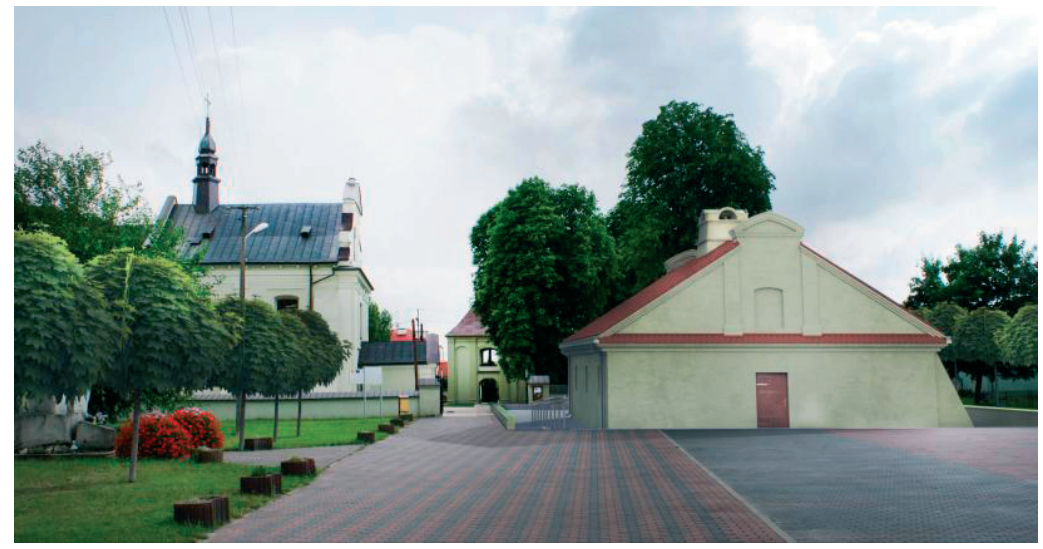

Rys. 24. Zespół sakralny - widok od strony północnej - wizualizacja projektu. Źródło: Oprac. własne

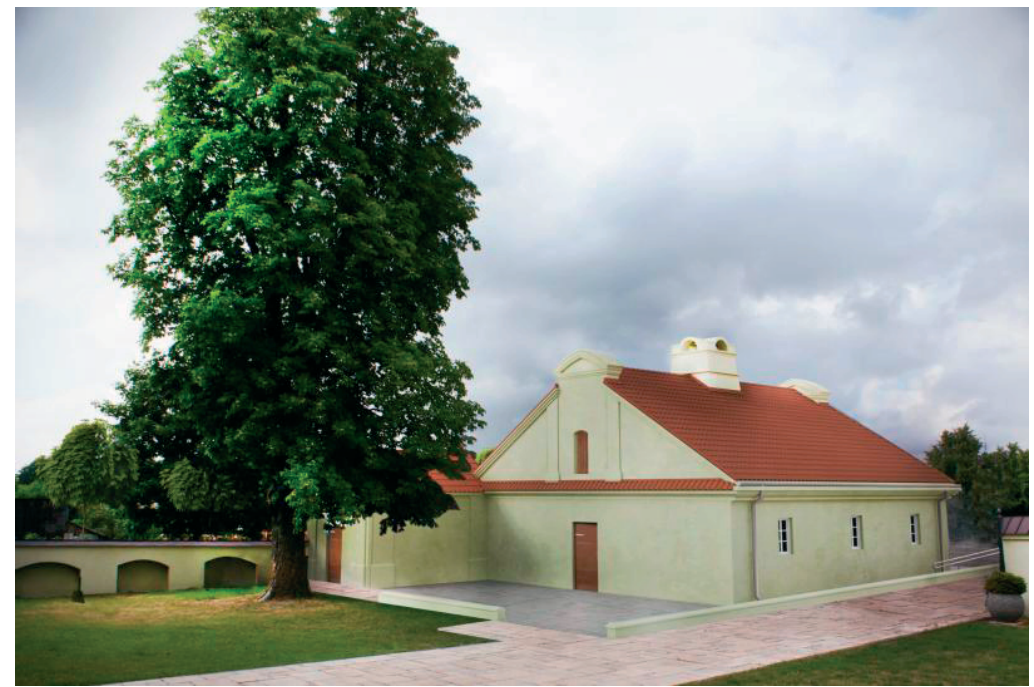

Rys. 25. Szpitalik wraz z kostnicą - widok od strony południowej - wizualizacja projektu. Źródło: Oprac. własne 


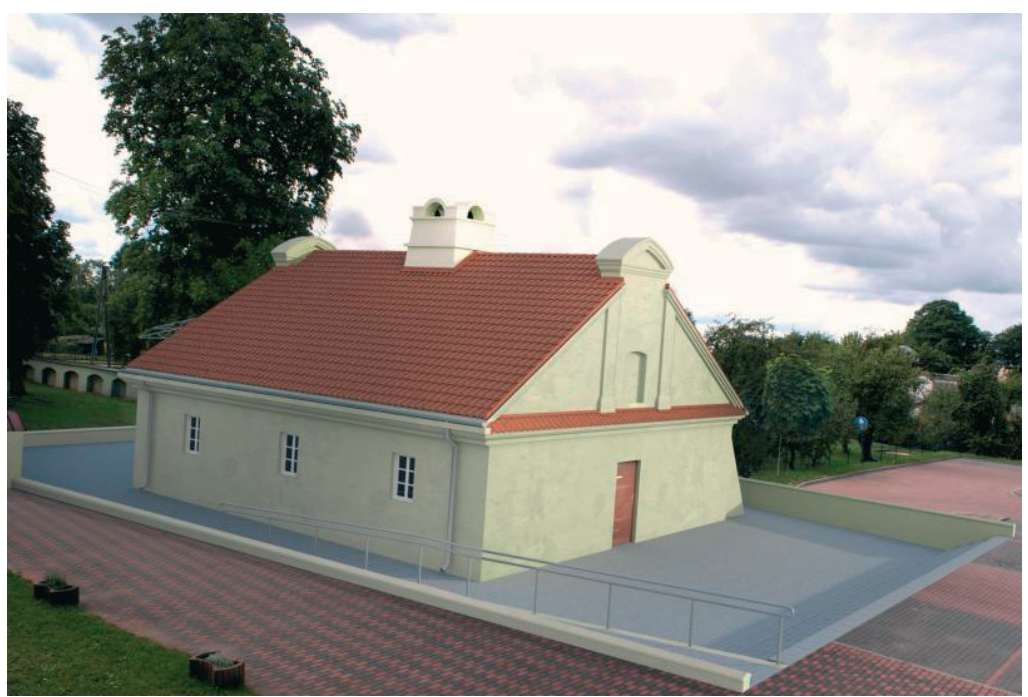

Rys. 26. Szpitalik - widok od strony północno-wschodniej - wizualizacja projektu z przywróceniem historycznego poziomu terenu. Źródło: Oprac. własne

\section{Wnioski}

Na mocy ustaleń konserwatorskich i miejscowego planu zagospodarowania przestrzennego Gminy Sawin, na budynek nałożone są ograniczenia. Nie może on być rozbudowywany. Bryła obiektu winna pozostać niezmieniona. Dopuszcza się wykonanie prac przy detalach architektonicznych pod warunkiem ich odtworzenia zgodnie ze stanem obecnym, z zastosowaniem tradycyjnych materiałów. Zachowaniu podlega układ pomieszczeń. Konserwator dopuścił możliwość odtworzenia gzymsu ścian podłużnych oraz w szczycie budynku.

Wszystkie prace dotyczące rozwiązań technologicznych lub napraw, a także wymiany lub usunięcia poszczególnych elementów i części obiektu należy poprzedzić procesem uzyskania pozwolenia na prowadzenie prac konserwatorskich i robót budowlanych wydawanym przez WUOZ Delegatura w Chełmie.

Przygotowanie projektu do realizacji było możliwe dzięki synergii postawy proboszcza - właściciela nieruchomości, Konserwatora Zabytków, który zaakceptował koncepcję projektu, władz samorządowych gminy oraz Regionalnego Towarzystwa Gminy Sawin głównego inspiratora idei. Wzajemna dobra współpraca pomiędzy w/w jednostkami umożliwiła powstanie szczególnej więzi, gdzie poprzez pasję wspólnego działania zyskują wszyscy, zarówno mieszkańcy jak i dobra kultury materialnej i intelektualnej. Tak właśnie należy rozumieć synergię.

\section{Załącznik}

- Biała Karta 3, oprac. mgr W. Pietrzak 


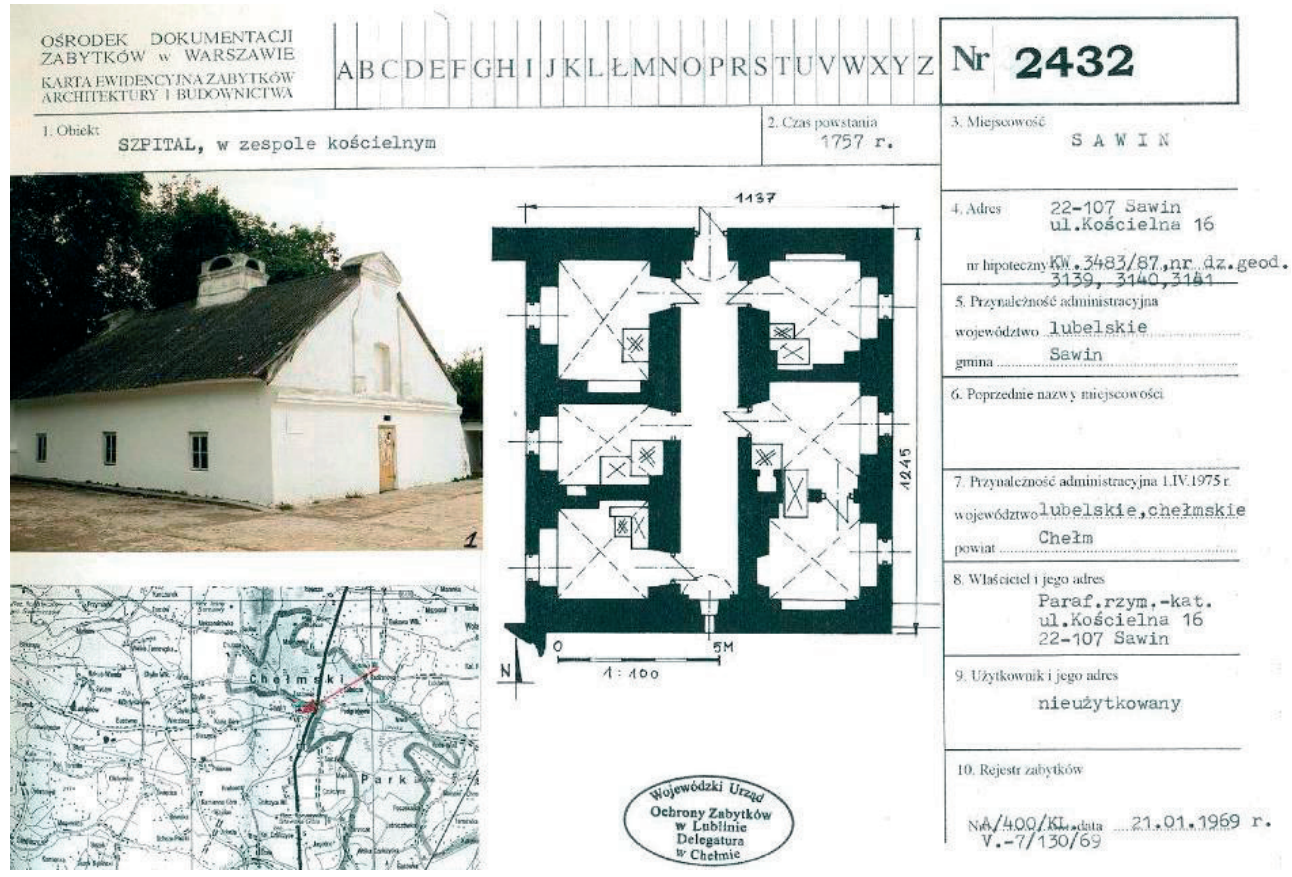

\footnotetext{
12. Autursy, historia obicktu, oksreslenie stylu.

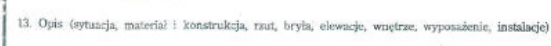

Pierwszy wzniesiony w 1611 roku, drewniany, obecny z $1757 \mathrm{r}$. fun dacji proboszcza Jóefa Suchockieso. Whyt kowany do polowy lat 60-tych.

Poznobarokowy

SYTUACJA :

zespoł koscielny połozony w srodku wsi, miedzy u1, Koscielna a Brzeska. Cmentarz przykoscielny prostokatny, opasany ceglanym murem, przy ktorym pozostałosci szpalerow lipowo-kasztanowych. Przy ul. Brzeskiej plac przedkoscielny. Na srodku cmentarza kosciot, orientowany. Przy ul. Koscielnej,w linii muru cmentarnego dzwonnica bramna, na jej osi w pn. boku muru brama wjazdowa. W narozniku pn, -zach. cmentarza kastnica, przy niej wysuniety poza mur cmentarny szpital. Wokot kosciota betonowe obejscie.Kostnica zwrócona frontem na pd.,pn.zach. naroznikiem taczy sie ze szpitalem.

MATERTAE I KONSTRUKCIA. glane

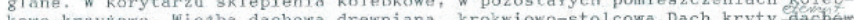
kowazkyzy. Siph d towe

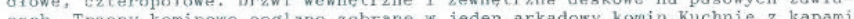
dwu- lub czterofajerkowe, z ogrzewalnikami, czesc z piecami chlebowymi.

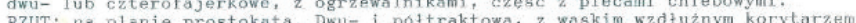
na srodku. W obu troktach po trzy pois

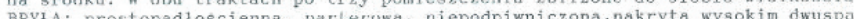
BRT.A. prostopadoscienna, par.e

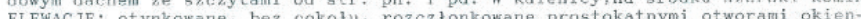

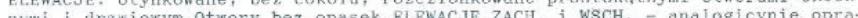
nyiti i drzwiowym. cowane, trojosiowe, ha ostach okna. ER tem oddzie lonym od korpusiom otwor drzwiowy. Szczyt a gory przelamany, zwienczony trojkatnym naczofkiem

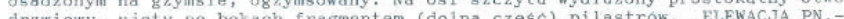
drzwiowy, ujely po hokeh fragmentem (doina opracowana jak pa. - jednonsiowa, na osi prostokatny otwor druwiowy w szczycie, nad gzymsen wienczdeyn odcinkowo zamkniota plycind, Naroza snymi szkarpami. komin ogzymsowany, na gzymsie czterech quaztarkadach.

WNETRE: Romunikacja z zewnatrz od str. pn., komunikacja wewnatrz oparta o wzdiuzny korytarz. Drzwi takze miedzy pd. pornieszczeniami traktu wsch. Korytarz nakryty sklepieniem kolebkowym. Tzby ze skiepieniami kolebkowo-krzyzowymi. We wszystkich pomieszczeniach cegtre posadzkl. liky doswietione pojedynczymi. oknaini. pomieszczeniach, przy scianach srodkowych dpowiednio od pn. " trak-

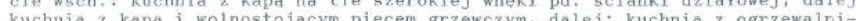
kuchmia z kapa wolnostojacym piecem grewcrym, dalej: kuchinia z ogrzewaini-

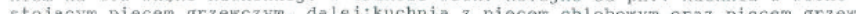

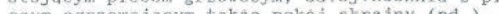
INSTAlAGj: kominowakze pokoj skrajny (par).
} 


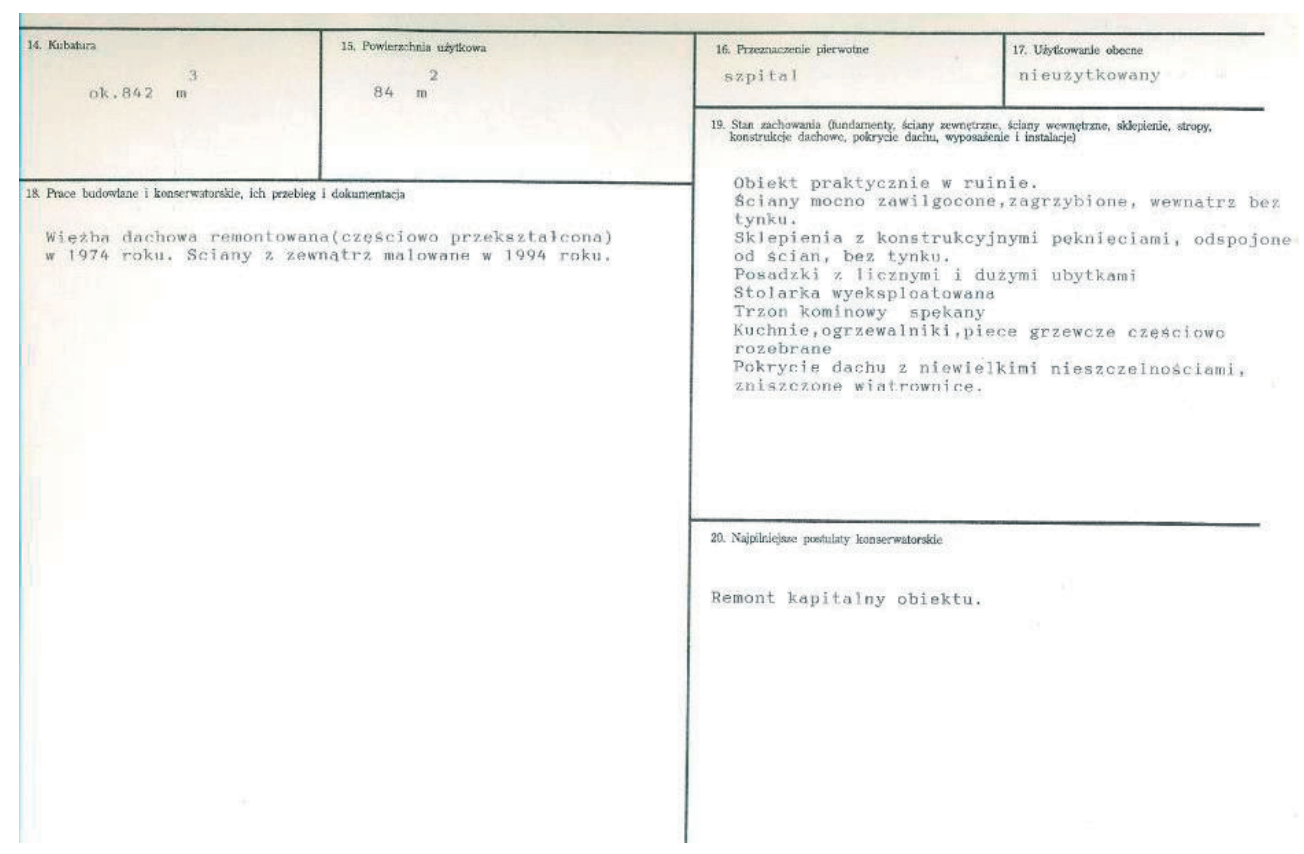

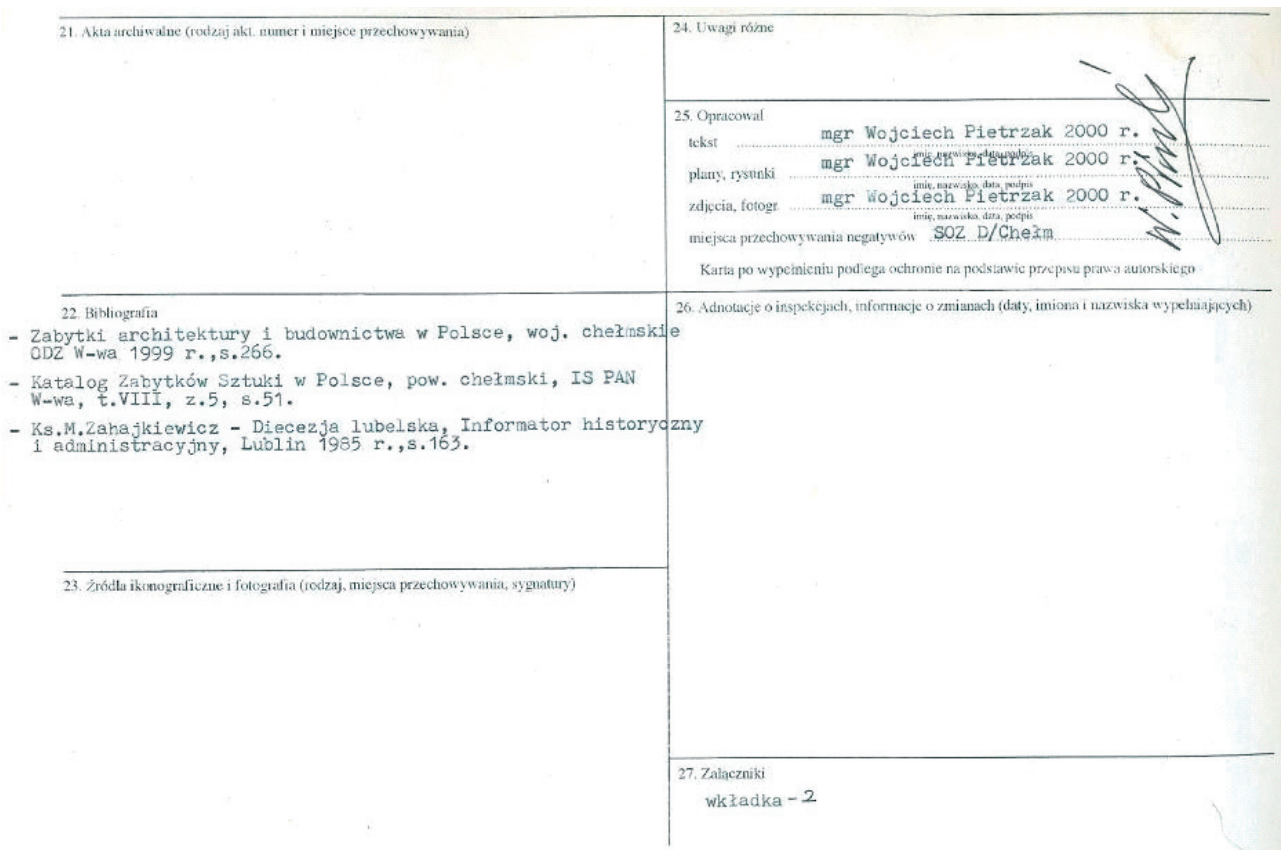




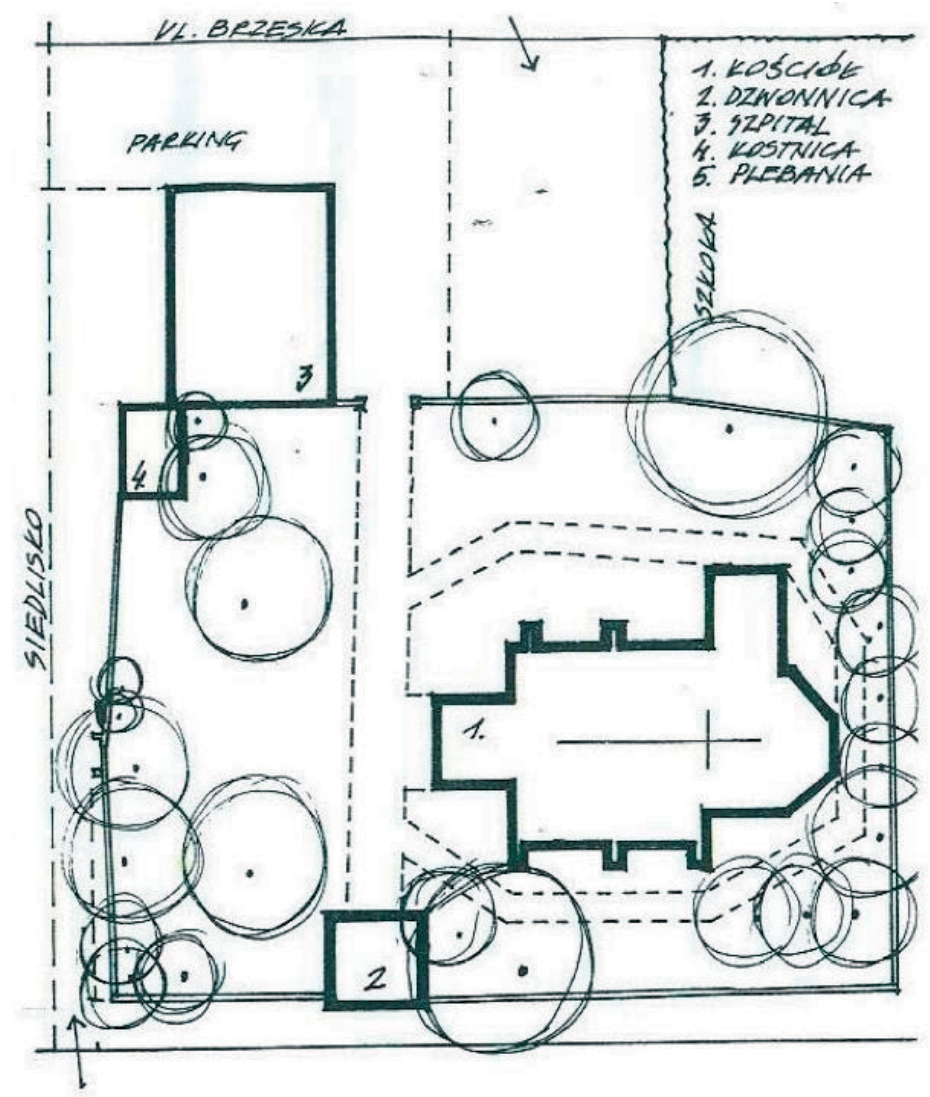

VL. KOSUELNA

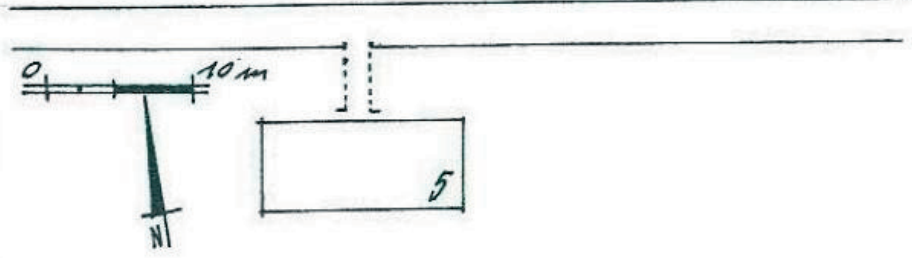

\section{Literatura}

6. Błaszczuk S., Ćwir J., Wiciński H. Dzieje Parafii Rzymskokatolickiej oraz innych kościołów i zwiazków wyznaniowych w Sawinie. Wyd. Drukarnia Kresowa Chełm, Sawin 2006.

7. Ćwir J. Dzieje Miasta Sawin do 1869 roku. Wyd. Regionalne Towarzystwo Gminy Sawin, Sawin 2010.

8. Siuchniński M. Miasta polskie w tysiącleciu. T.1-2, Zakład Narodowy im. Ossolińskich, 1965 Wrocław - Warszawa - Kraków.

9. Materiały z sympozjum naukowego z okazji XXXV-lecia Wydziału Budownictwa i Architektury Politechniki Szczecińskiej, Architektura, Zakład Poligraficzny Politechniki Szczecińskiej "ZAPOL", 1981 Szczecin.

10. Znamierowski A. Insygnia i herby polskie. Świat Książki, Warszawa 2003.

11. Łoziński W. Prawem i lewem. Obyczaje na Czerwonej Rusi w pierwszej polowie XVII wieku. Wyd. Iskry, 2005 Warszawa. 


\title{
The use of public utility facility entered into the register of monuments to fulfill the contemporary occupancy function
}

\author{
(Based on the example of the almshouse - the hospital situated \\ in the sacral complex of roman catholic parish of Transfiguration \\ of our Lord in Sawin, within Chelm county, Lublin voivodship)
}

\author{
Mieczyslaw Brzozowski, Katarzyna Swięcicka-Brzozowska \\ e-mail: brzozowskipulawy@op.pl,ksbrzozowska@wp.pl
}

\begin{abstract}
This article describes the concept of the use of Hospital-almshouse in Sawin, considered a historic object of public utility, for contemporary occupancy function. In the introduction the author presents the history of the object created on the basis of both studies as well as documents and expert opinions of the competent authorities and administrative units. The next part features the present building condition of the facility made on the basis of a detailed survey conducted with the use of the latest specialist equipment. The final part provides the assumptions of the project aiming at the revitalization of the object which will serve the Regional Society of Sawin Commune in order to achieve its statutory purposes.
\end{abstract}

Keywords: historical building, contemporary function. 
